\title{
A survey of life insurance efficiency papers: Methods, pros \& cons, trends
}

\author{
William Wise a $^{*}$
}

${ }^{a}$ Sydney, NSW, Australia

\begin{tabular}{l}
\hline C H R O N I C L E \\
\hline Article history: \\
Received October 5, 2016 \\
Received in revised format \\
November 112016 \\
Accepted November 202016 \\
Available online \\
November 22 2016 \\
\hline Keywords: \\
Life Insurance \\
Efficiency \\
Inputs/Outputs \\
Literature Review
\end{tabular}

\begin{abstract}
A B S T R A C T
This survey research paper explores the methods most commonly used in over 190 studies determining life insurance efficiency. The purpose is to provide an overview of life insurance efficiency studies and guidance as to the (dis)advantages of the different techniques used plus their applicability to life insurance. An evaluation of the different approaches is undertaken plus an examination of the numbers and trends of methods and aspects of life insurance efficiency measurement. This paper also discusses the fundamental elements of life insurance efficiency estimation, such as the set-up and form of outputs and inputs. Findings include that the focus of life insurance efficiency studies considering individual nations has changed. Additionally data envelope analysis is the technique used most commonly with stochastic frontier analysis next. Another main result is that output proxies (akin to) premiums and investment income is utilized most. This study allows practitioners to determine the best techniques to employ in life insurance efficiency studies. Moreover an evaluation by regulators of the value and applicability of such studies is facilitated. Therefore an assessment of the overall results of efficiency studies is possible. In addition ideas for potential further research are discussed. Consequently this review will be useful to both practitioners and regulators concerned with this area.
\end{abstract}

\section{Introduction}

This paper explores the methods most commonly used in over 190 studies that determine life insurance efficiency, an area that is gaining in recognition as being important to investigate. In addition an evaluation of the different approaches is undertaken as well as an examination of the numbers and recent trends of methods and some aspects of life insurance efficiency measurement. This article enhances and improves upon the more limited studies such as Berger and Humphrey (1997), Cummins and Weiss (2000) and Eling and Luhnen (2010a) making contributions such as an overview of life insurance efficiency studies performed since 1983 and guidance as to the advantages and disadvantages of the different techniques used therein plus their applicability to life insurance. This paper also shows how the most fundamental elements of life insurance efficiency estimation, such as the set-up and form of outputs and inputs, have been coped with. Therefore an assessment of the overall results of 
efficiency studies is possible. Additionally ideas for potential further research are discussed. Consequently this review will be useful to both practitioners and regulators concerned with this area.

This article continues with Section 2 which describes the most common methods of determining efficiency and some of their main advantages and disadvantages. Section 3 discusses output and input proxies used in life insurance efficiency studies while Section 4 exhibits the numbers and trends of papers, output proxies and input proxies. Section 5 concludes and postulates ideas for possible further research.

\section{Most Common Methods of Determining Efficiency}

The most common methods utilized to determine life insurer efficiency number seven comprising two nonparametric, three parametric, one semi-parametric and the Bayesian. As true efficiency is unknown it is impossible to tell which approach gives best outcome (Hussels \& Ward, 2004) so the process chosen should depend on items such as the purpose of the study and the type of data available (Hjalmarsson et al., 1996).

The two nonparametric approaches, data envelopment analysis (DEA) and free disposal hull (FDH), do not specify a form for the underlying production relationship between inputs and outputs. The linear programming technique DEA creates frontier observations with no other (linear combination) of decision making units (DMUs) having at least as much (little) output (input) for a given set of inputs (outputs). The technique is called data envelopment because the data of the most efficient DMU "envelops" the data of the others. FDH, introduced by Deprins et al. (1984), is a special case of DEA in that the latter allows for linear combinations of observed input sets and FDH assumes no such replacement is possible (Bauer et al., 1998; Saad et al., 2006). Hence the production possibilities of FDH are only the vertices calculated incorporating DEA and the points calculated using FDH that are interior to them. This leads to the average efficiency estimated by the FDH method being at least as large, and often larger, than that when applying DEA.

The three parametric techniques, stochastic frontier analysis (SFA), thick frontier analysis (TFA) and the distribution-free approach (DFA), specify a functional form for the efficiency frontier. The DFA evaluates each firm's inefficiency as the difference between its average residual and that of an institution on the efficiency frontier. This results in the DFA assuming that over time the efficiency of each company exhibits little change and the "random errors average to zero" (Berger \& Humphrey, 1997; Schmidt \& Sickles, 1984).

SFA sets each firm's inefficiency as its residual from the efficiency frontier and usually takes the form

$$
M_{i}=f\left(k_{i} ; \beta\right) \exp \left(v_{i}-u_{i}\right)
$$

where $f\left(k_{i} ; \beta\right)$ is the functional form of the efficient frontier, $M_{i}$ is the measured value, the $k_{i}$ values are independent variables and the $\beta$ parameters are to be estimated. Finally, noise is represented by exp $v_{i}$ and $\exp u_{i}$ represents inefficiency. These latter two form the residual, which therefore has two pieces, a random error term and the efficiency term with the former usually assumed to follow a symmetric distribution, such as the standard normal. The efficiency term is usually set as a non-negative asymmetric distribution such as the half-normal, truncated normal or gamma.

TFA is similar to SFA except that it assumes that deviations from the predicted efficiency within the highest and lowest quartiles, quintiles or other sets of the observations that are utilized represent random error. The deviations between these sets may occur in either the intercepts or in the slope parameters (Bauer et al., 1998) and thus represent inefficiencies. Therefore the frontier is thick in the sense that 
on a graph it would not be seen as a line but as a polygon. As opposed to point calculations for individual firms TFA gives an assessment of the general level of the overall efficiency of an industry.

Fully parametric approaches employ a fully specified model with the full distributions of $v_{i}$ and $u_{i}$ being known up to the specific values of the parameters. In contrast the semi-parametric methods keep the essential structure of the stochastic frontier but relax either one assumption restriction in the model or a specific distribution for $v_{i}$ and/or $u_{i}$ (Greene, 2008). To keep the structure of the stochastic frontier a functional form is needed with the most common used being the Fourier flexible (FF). Here the SFA functional form $M_{i}=f\left(k_{i} ; \beta\right)$ is a "kernel" with terms incorporating sine and cosine functions added and because the sine and cosine functions are orthogonal, the FF functional form can globally approximate any function well.

The Bayesian procedure utilizes information, e.g. from economic theory, to estimate the model parameters. The estimation is called a prior probability distribution function (pdf). With SFA, for example, the prior distribution may be $p(\boldsymbol{\beta}, \sigma)$ where $\boldsymbol{\beta}$ represents parameters $\beta_{1}, \beta_{2}, \beta_{3}, \ldots$. The likelihood function $L(\boldsymbol{x} \mid \boldsymbol{\beta}, \sigma)\left(\boldsymbol{x}\right.$ represents the data points $\left.x_{1}, x_{2} x_{3}, \ldots\right)$ is next calculated. Then as Bayes' Theorem shows that the posterior pdf $p(\boldsymbol{\beta}, \sigma \mid \boldsymbol{x}) \alpha L(\boldsymbol{x} \mid \boldsymbol{\beta}, \sigma) p(\boldsymbol{\beta}, \sigma)$, a marginal pdf $p\left(\beta_{k} \mid \boldsymbol{x}\right)$ for each element of $\boldsymbol{\beta}$ can usually be determined and the probability that $\beta_{k}$ lies in an interval evaluated.

\subsection{The Nonparametric Methods - Advantages and Disadvantages}

One advantage of the nonparametric methods is that they are simple and associated with easy calculations (Coelli et al., 2005) as they do not necessitate the full specification of the functional form or distributions of the inefficiency or random noise terms (Berger \& Humphrey, 1997; Cummins et al., 2010; Leverty et al., 2004). As a result specification errors (Cummins et al., 2010) and many subjective features are circumvented (Qiu \& Chen, 2006). In addition Sinha and Chatterjee (2009) and Trigo Gamarra \& Growitsch (2008) note that not requiring a specific functional form of the underlying technology makes the nonparametric approaches especially useful when looking at service industries such a life insurance because for them there is limited information about said underlying production technology (Fecher et al., 1993).

An advantage of DEA specifically is that it can be applied to distinguish between (pure) technical efficiency versus scale efficiency and allocative efficiency (Chen et al., 2008; Cummins et al., 1999a; Hardwick et al., 2003). It can also allow for the assessment of the directions and potential for improvement for each inefficient DMU (Chen et al., 2008; Cummins \& Weiss, 2000). Other advantages of DEA are that it results in consistent estimators (Banker, 1993) even when the variances of regression disturbances exhibit heteroscedasticity (Banker et al., 2004). Furthermore the asymptotic distribution of the DEA inefficiency estimators is the same as their true distribution (Banker, 1993).

A second nonparametric method, FDH, was introduced by Deprins et al. (1984), as they disapproved of DEA assuming a convexity of the efficient frontier. The FDH technique eliminates the convexity assumption (Naini \& Nouralizadeh, 2012) even though some industries oblige it (Cummins \& Weiss, 2000). Another advantage of FDH is that its less arbitrary assumptions may lead to a more accurate fit to the data than does DEA (Tulkens, 1993; Vanden Eeckaut, Tulkens \& Jamar, 1993). Consequently efficiencies calculated employing the FDH approach are actual observations as opposed to DEA's incorporation of a built production frontier and so seem more credible (Tulkens, 1993). Moreover FDH removes the bias of DEA due to fully efficient DMUs being utilized repeatedly in DEA to create more theoretical firms (Ennsfellner et al., 2004).

The main drawbacks with nonparametric methods are the use of a deterministic procedure and an assumption of no random error. Berger \& Humphrey (1991) notes that efficiency frontier construction incorporates an assumption of no measurement errors and, more importantly, a change in the measured efficiency of a DMU not depending on good or bad luck (Berger \& Mester, 1997; Cummins \& Weiss, 
2000; Simar \& Wilson, 1998). With respect to life insurance as almost every facet of it, e.g. mortality, morbidity, lapse and interest rates, contains a large element of randomness, excluding randomness presents problems. Furthermore if some companies get very lucky results (i.e. not due to capability) then the efficiency scores of other companies will be unduly low (Bauer et al., 1998). One more difficulty is that these techniques ignore accounting rules which distort the appraisal of inputs or output values (Berger \& Humphrey, 1997). The outcome of the foregoing problems is that any calculation anomalies are recorded as a change in efficiency rather than a computation error. Additionally efficiency estimation of other DMUs may be distorted if compared to one suffering from one of these problems (Berger \& Humphrey, 1991). DEA assumes that the range of available inputs is similar across all DMUs (Dyson et al., 2001). However this is not true in many life insurance markets. For example in the United States life insurance industry there is a large disparity in company asset size as shown by the largest firm in 2014 having over $\$ 390$ billion in assets and the smallest having less than $\$ 100$ thousand. The huge difference is further demonstrated as the tenth largest life insurer by asset size has over $\$ 161$ billion and the $100^{\text {th }}$ has just over $\$ 10$ billion in assets. In Canada the largest company in 2014 had over $\$ 190$ billion in assets and the smallest had less than $\$ 3$ million and for Australia the corresponding values were $\$ 87$ billion and $\$ 13$ million. Hence, for example, the types of assets obtainable to smaller firms may not be the same as for the larger. ${ }^{1}$ Also, institutions issuing different lines of business or that are in different locations may not draw upon or have available the same inputs (Barros et al., 2005a).

Another significant drawback with DEA and FDH is that they were designed to be applied to not-forprofit DMUs (Charnes et al., 1978) that do not have the usual economic goals such as profit maximization or cost minimization (Sun \& Zhong, 2011). Additional deficiencies include that 1) the frontier can be shaped by the data, ${ }^{2} 2$ ) the calculation is very susceptible to the number of exogenous constraints used (Berger \& Humphrey, 1991; De Luca Cardillo \& Fortuna, 2000) and to input/output specification and outliers (Ennsfellner et al., 2004; Deng, 2010), 3) there is no accounting for input or output prices and so no evaluation of allocative inefficiency (Berger \& Mester, 1997) thus leading to an upward bias in efficiency scores (Berger \& Humphrey, 1997; Simar \& Wilson, 1998), 4) because, as Cummins \& Weiss (2000) remarks, relative prices cannot be used to compare non-alike companies as only the data of entities closest in type to that being assessed are used in quantifying the inefficiency of said entity (Avkiran, 2002; Berger \& Mester, 1997), 5) firms can have very high efficiency scores simply because few others have analogous inputs, outputs or related observations (Bauer et al., 1998), 6) the performance of the interaction between components of a DMU cannot be determined (Kao, 2009; Sexton \& Lewis, 2003), 7) an underlying model or reference technology results in a bias in DEA assessments (Kittelsen, 1999) and 8) different returns to scale assumptions in any underlying technology lead to completely different conclusions (Fare et al., 1994; Ray \& Desli, 1997). The outcome of some of these problems is that nonparametric methods allow only for an analysis of technological, not economic, optimization (Berger \& Humphrey, 1997; Huang, 2007).

\subsection{Overcoming the Disadvantages of the Nonparametric Methods}

Several processes of overcoming the aforementioned drawbacks of DEA are employed in the life insurance efficiency literature. Some of the most common of these are the utilization of bootstrapping, slacks, range adjustment and an assurance region.

Bootstrapping is designed to overcome the problem of uncertainty related to the measurements arrived at via the nonparametric approaches (Mahlberg \& Url, 2010; Ubl, 2010), which was seemingly not considered (Assaf et al., 2012). The bootstrap procedure was introduced by Efron (1979) as more applicable and dependable than the "jackknife." The idea is to investigate the sensitivity of efficiency

\footnotetext{
${ }^{1}$ This can be partly due to regulations.

${ }^{2}$ As random error, accounting rules and measurement errors are ignored
} 
estimates to differences in data samples by first replicating the data generating process (DGP). Then the original estimator is applied to each replication. In this way the simulations can be applied to imitate the original (unknown) sampling distribution (Berger \& Humphrey, 1997, Simar \& Wilson, 1998). The bootstrap of the DGP approximately replicates the variation due to sampling of the calculated efficiency frontier, therefore permitting an exploration of its sensitivity (Simar \& Wilson, 1998) and associated confidence intervals (Simar \& Wilson, 2000). Bootstrapping enables the testing of concepts such as statistical significance of the disparities in efficiency estimates, statistical inference and bias correction of estimators (Simar \& Wilson, 2000; Leverty et al., 2009) and hypotheses regarding the underlying technology (Badunenko et al., 2006; Simar \& Wilson, 1998).

Even so bootstrapping has the disadvantage that it accentuates the problem that the nonparametric methods do not account for random noise of the data (Simar \& Wilson, 1998) in that addition more noise is introduced into the data with bootstrapping (Simar \& Wilson, 2008).

DEA incorporates a radial technique which has a fundamental drawback in that it does not illustrate all of the input decreases or output increases, i.e. "slacks" (Sinha, 2007a). Hence it cannot identify potential efficiency increases from such changes (Tone, 1998). Tone (1998) introduced a slacks-based DEA method to overtly include input overindulgences and output deficiencies in the objective function (Drake et al., 2006). The consequence is that if a DMU has larger slacks than a second, the first is deemed less efficient (Tone, 1998) such that with slacks inefficiency can be measured as a product of input and output inefficiencies (Sinha, 2015). So the optimal result is when a DMU has no input and output slacks (Drake et al., 2006).

The range-adjusted DEA approach builds on slacks based DEA. The inefficiency scores calculated are "dimensionless" with the first step being dividing each slack variable by its range over the DMUs. Then, using the set-up leading to the initial DEA efficiency scores, the sum of 1) the above quotients over 2) the total number of inputs and outputs $\varepsilon[0,1]$ which becomes the inefficiency scores of the DMUs. Accordingly a DMU is deemed to be fully efficient if and only if there are no slacks in any inputs or outputs (Brockett et al., 2005; Leverty \& Grace, 2008). Positive characteristics of the rangeadjusted method include that the efficiency scores do not alter if either the location or scale of outputs or inputs change (Brockett et al., 2005) and said scores are robustly monotonic and can thusly be used to rank DMUs (Cooper et al., 1999; Leverty \& Grace, 2008).

Another mechanism of dealing with slacks is assurance region DEA, introduced by Thompson et al. (1986), which limits input and output shadow prices. The limits are achieved by setting bounds on the ratios of input and output shadow prices to each other (Sinha, 2007a). Therefore the isoquant is changed so that, at the most efficient points, slacks cannot be present on the radial projection of any combination of inputs and outputs onto the changed isoquant. If such slacks are present there is too much of either an input or output which puts the linear programming solution, found in terms of the ratios of the shadow prices, outside the set shadow price restriction (Sinha, 2007a; Thompson et al., 1986).

\subsection{The Parametric Methods - Advantages and Disadvantages}

Much like the nonparametric, the parametric methods have both advantages and disadvantages. Other than advantages corresponding to the foregoing disadvantages of the nonparametric methods, an advantage of the parametric techniques is that they absorb some effect of heterogeneity in inputs and outputs (Cummins \& Weiss, 2000). Other advantages include that they enable statistical testing of hypotheses and calculating confidence intervals (Hjalmarsson et al., 1996).

The main difficulty with the parametric approaches is the necessity of correct functional form and error term distributions to obtain unbiased parameter estimates. Not assuming the correct form or distributions can lead to specification errors such that 1) either efficiency determinations can be mixed 
up with said specification error (Bauer et al., 1998; Berger \& Humphrey, 1991; Cummins \& Weiss, 2000) or 2) either the efficiency or random error measures do not fit the observed data (Berger \& Humphrey, 1992; Greene, 1990; Stevenson, 1980). Moreover the parametric methods require the identification of a production, cost or profit function where the largest problem is separating the efficiency scores from luck and random error properly (Berger \& Humphrey, 1992). As well, such a function assumes an underlying production relationship, which may not be true (Drake et al., 2006; Hjalmarsson et al., 1996).

Some advantages and disadvantages of specific parametric techniques are described in the following.

SFA has key advantages in that it can differentiate between efficiencies and measurement error (Koop et al., 1994) and exhibits internal consistency and furthermore is easy to apply (Greene, 2008). But notwithstanding these any difficulty concerning the specification errors are emphasized with the utilization of the two error terms which must be separated properly (Koop et al., 1994).

DFA was originated in Schmidt \& Sickles (1984) and Berger (1993) with one advantage being that it only involves a small amount of theoretical assumptions with respect to the data and the production process (Ryan, Jr., \& Schellhorn, 2000). One more plus concerns how DFA handles random error. DFA does not assume a distribution of random error (as does SFA) and DFA does not assume that differences between groups of companies are all inefficiencies (as does TFA) (Bauer et al., 1998).

However DFA has the same drawback regarding random error as does DEA. Another problem with DFA, originally pointed out in Schmidt \& Sickles (1984), is that as average residuals are employed a change in, for example, technology or regulations affecting the efficiency of all DMUs examined results in the DFA estimating each company's average inefficiency over time (Berger et al., 1997; Berger \& Humphrey, 1997). Such an evaluation is problematic as it is more desirable to appraise efficiency against the frontier at one point in time such as just before or after said change.

TFA has an advantage in that it needs little in the way of assumptions and so, compared to SFA, may be less prone to the specification errors mentioned previously (Berger \& Humphrey, 1992; Ennsfellner et al., 2004). For instance there is no requirement for the regressors to be uncorrelated with the efficiencies (Berger \& Humphrey, 1992) and the only assumptions necessary as to efficiency and random error are that the highest and lowest quartiles incorporate different efficiencies and that there is random error within said quartiles (Berger \& Humphrey, 1997). In addition there is less likelihood of the bias seen in DEA efficiency estimates (Berger \& Humphrey, 1991) and TFA is not subjected to the influence of outliers (Bikker \& van Leuvensteijn, 2008).

A weakness of TFA is that the sets used may be determined using the dependent variables of the regressions which can bias the coefficient estimates (Berger \& Humphrey, 1992). As well TFA requires data that is highly dispersed (Ennsfellner et al., 2004).

\subsection{The Semi-Parametric and Bayesian Methods}

Semi-parametric methods have an advantage in that the properties of the cost or profit function can be established from the data (Koop et al., 1994). A deficiency of the semi-parametric methods is that efficiency calculations can be very misleading if an inappropriate functional form is chosen. When using $u_{i}$ and $v_{i}$ terms their separation is an important consideration and can be the least robust to arbitrary assumptions (Koop et al., 1994).

As stated earlier the most common functional form applied with the semi-parametric method is the FF. One disadvantage of utilizing a FF functional form is that the sine and cosine functions of the FF form have no economic interpretation making it difficult to analyze any outcomes obtained. Moreover the 
sine and cosine functions do not satisfy the usual regularity conditions, such as increasing monotonically and being strictly quasi-concave (Yue, 1991), even though this drawback can be overcome by employing the procedure of Gallant \& Golub (1982), forcing quasi-convexity of the consumer's individual utility function to easily make the FF functional form regular (Barnett et al., 1991). Furthermore, a FF form can overfit the random error contained in the data (Koop et al., 1994; Yue, 1991) as a large enough FF functional form will ultimately attain a perfect fit because noise will be looked at as irrational behavior (Barnett et al., 1991). Also because $n$-order trigonometric terms ${ }^{3}$ are included there is an increased chance of multicollinearity among the function's terms which hinders an assessment of the meaning of the coefficient estimates (Ward, 2002). Additionally Altunbas \& Chakravarty (2001) reports that, even though compared to a translog functional form, a FF functional form may have a better fit to the data; it may have a worse predictive ability. In fact Marie et al. (2009) finds that translog form outperformed the FF form.

There are other semi-parametric methods in the literature. One of these is the Muntz-Szatz expansion of Barnett et al. (1991) that Koop et al. (1994) relates fits only that part of the data that is globally regular, thereby eliminating the risk of overfitting.

Another semi-parametric process, used by Fan et al. (1996), is based on a production model

$$
y_{i}=g\left(x_{i} ; \beta\right) \exp \left(v_{i}-u_{i}\right)
$$

where $g\left(x_{i} ; \beta\right)$ is the functional form of the efficient frontier, $y_{i}$ represents the outputs, and $x_{i}$ the inputs of firm $i$ and the $\beta$ parameters are to be estimated. Finally, noise is represented by exp $v_{i}$ and exp $u_{i}$ represents inefficiency. In the Fan et al. (1996) model the functional form is $g\left(x_{i} ; \beta\right)=w_{i}^{\prime} \beta+m\left(z_{i}\right)$ where the functional form of $m($.$) is unknown.$

A third semi-parametric technique, incorporated by Park \& Simar (1992), is

$$
y_{i t}=B(h)+\beta^{T} x_{i t}+\alpha_{i}+\varepsilon i t
$$

where $y_{i}$ represents the outputs, and $x_{i}$ the inputs of firm $i$ with the $\beta$ parameters to be estimated. $B(h)$ is the upper bound of the unknown density $h$. The $\alpha_{i}-B(h)$ corresponds to the technical inefficiency of the firm $i$ (with the $\alpha_{i}$ being iid from $h$ ) and $\varepsilon_{i t}$ is noise. The paper gives an asymptotic lower bound of $\beta$ and an efficient estimator of $\beta$ that attains said lower bound. Then the predictors of $\alpha_{i}$ are built using the $\beta$ estimates. Lastly an estimator of $B(h)$ is shown which gives estimates of the frontier function and so the technical inefficiencies.

Adams et al. (1999) specifies a semi-parametric approach similar to Park \& Simar (1992). This study begins with the panel-data model

$$
y_{i t}=\beta^{T} x_{i t}+\gamma^{T} y_{i t}+\alpha_{i}+\varepsilon_{i t}
$$

where $y_{i}$ represents the outputs, $y^{*_{i}}$ represents the normalized (by the last $y_{i}$ ) outputs, and $x_{i}$ the inputs of firm $i$ and the $\beta$ and $\gamma$ parameters are to be estimated. Finally $\alpha_{i}$ represents the constant level of inefficiency and $\varepsilon_{i t}$ is noise.

Adams et al. (1999) draws upon a semi-parametric method where no parametric assumptions are made for the inputs. This procedure allows the forcing of necessary restrictions, particularly having the output distance function be linear homogenous, on outputs and so lets a correlation between a subset of the regressors and efficiency scores be set up (Adams et al., 1999).

\footnotetext{
${ }^{3} n$ is typically two, three of four.
} 
One difficulty with the Bayesian approach is the need to choose a reasonable prior pdf without which the estimates with respect to each $\beta_{k}$ may be useless or nonsensical. Moreover the prior pdf is selected by the researcher which can lead to problems such as bias or error in their views. As well it may be difficult to calculate the marginal pdfs as doing so can require complex integration.

\section{Output and Input Proxies}

As efficiency is an evaluation of the ability of a company to manufacture outputs from inputs it is necessary to designate measures to use as output and input proxies (Ennsfellner et al., 2004; Leverty et al., 2009). The difficulty regarding life insurance is, as its output is intangible services, the output volume must be approximated by proxy variables (Leverty et al., 2004; Weiss, 1986). However there is a debate in the literature as to which of the two basic sets of prevalent output proxies used, 1) reserves (or their change) and claims and 2) premiums and investment income is more appropriate.

Reasons given for utilizing (change in) reserves include that 1) such a value is the best proxy for the volume of underwriting, claims handling and other real services as it is highly correlated with both the numbers of claims and policies (Cummins et al., 1999a; Klumpes, 2006; Leverty et al., 2004), 2) reserves accounts, as a supplement to past losses accounted for by using claims, for expected future losses (Cummins \& Rubio-Misas, 2001; Kim \& Grace, 1995) and 3) the change in reserves is good proxy for the intermediation of the concurrent year because of the idea that the reserve value will equal the value of assets held by the company (Cummins et al., 1999a; Karim \& Jhantasana, 2005; Trigo Gamarra \& Growitsch, 2008).

Claims is linked with the use of (change in) reserves as an output proxy ${ }^{4}$ with the rationale including 1) claims represent payments received by policyholders and are good proxies as they measure the amount of funds pooled and redistributed (i.e. for losses) by insurers (Berger et al., 2000; Cummins et al., 1999a; Tone \& Sahoo, 2005), 2) that such redistribution is the object of risk-pooling (Cummins \& Rubio-Misas, 2001; Tone \& Sahoo, 2005), 3) versus reserves representing future expected losses, claims equal current expenses and losses (Cummins et al., 2004; Trigo Gamarra, 2008) and 4) claims are a good proxy for real services as the amount of claims settlement and real management services are highly correlated with loss amounts (Berger et al., 2000; Cummins et al., 1999a).

The other basic set of output proxies is premiums and investment income. Considering life insurance Blair et al. (1975, p. 185) says that "[p]remiums written has been selected as the measure of output size, which is analogous to using dollar sales volume as a proxy for output" and Fecher et al (1993, p. 81) states that "[p]remiums collected directly concern the technical activity of an insurance company. It reflects the ability of an insurance company to market products, to select clients, and to accept carrying risks." Other life insurance research making similar statements regarding premiums as output include Hussels \& Ward (2004) and Ward (2002). Furthermore Diewert (1995, p. 41) explains that "gross premiums paid rather than net [i.e. of claims] premiums ... is in agreement with our suggested nominal measure of output" and Hu et al. (2009) points out that premiums are the basis for insurer expenses and profits.

With respect to annuities Segal $(2002$, p. 84) remarks that "[a]ssuming a positive spread, the larger the annuity considerations, the higher is the expected profit. Hence, a plausible proxy for this output is annuity considerations, which represent the increase in the earnings base of this line of business." As accident and sickness mostly takes into account risk (as opposed to intermediation) if "the risk associated with such policies is priced correctly, premiums are a good proxy for risk" (Segal, 2002, p.

\footnotetext{
${ }^{4}$ Claims are referred to as incurred benefits in some papers (even though the term incurred benefits is used by some papers to include changes in reserves).
} 
84). Some papers including Greene \& Segal (2004), Mansor \& Radam (2000) and Rees et al. (1999) advance alternatives to premiums for an output proxy such as policy count and face value. Reasons given include that 1) premium increases influence the output amounts (Bernstein, 1998), 2) premiums are not quantity of output as they are the product of price and quantity (and so are revenue) (Cummins \& Zi, 1997; Leverty et al., 2004; Yuengert, 1993) and 3) there can be premium differences between large and small insurers (Boonyasai et al., 2002; Yuengert, 1993).

Investment income is linked with the use of premiums as a proxy for output. Several studies for instance Berger et al. (2000), Cummins \& Rubio-Misas (2001) and Greene \& Segal (2004) use asset values as a proxy for output. However investment income is considered by some to be a better proxy because it is a flow value rather than a static value. In addition investment income gives an idea of the expertise of insurers concerning their investment competence (Wu \& Zeng, 2011). Hussels \& Ward (2004, p. 9) agrees as "life insurance companies collect funds in advance of paying benefits [and t]he process of working with the[se] funds during the time lag is referred to as the intermediation service."

The treatment of inputs is less varied than outputs as labor and capital is recognized by virtually all writers. The other values incorporated as input proxies vary somewhat with material and/or business services, or similar terminology, being most common.

\section{Counts and Trends}

\subsection{Number of Papers}

The number of papers that have explored life insurance efficiency has steadily increased as seen in Fig. 1 below which shows the number of studies in the survey year-by-year (starting in 1992):

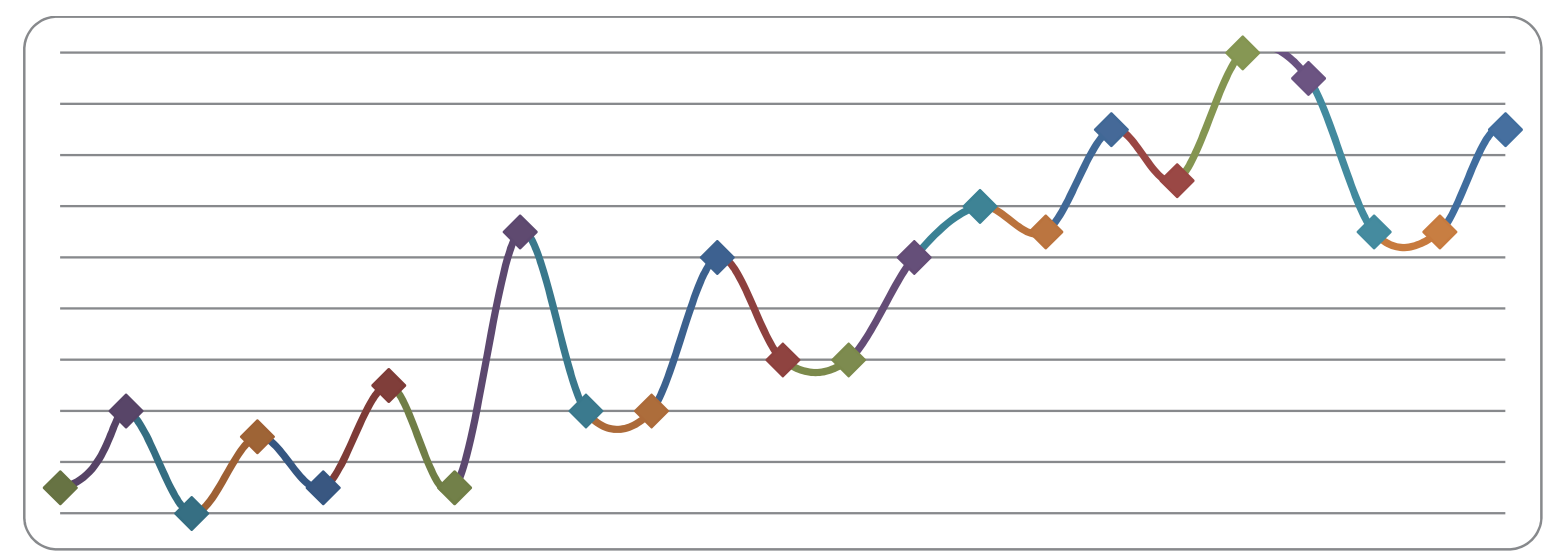

One paper from each of 1983 and 1986 and seven from 2015 also in the survey

Fig. 1. Number of Life Insurance Efficiency Studies (Year-by-Year)

The steady increase in research investigating life insurance efficiency indicates that it is being thought of as more critical in both the life insurance industry and the financial services industry as a whole. For papers that calculate life insurance efficiency, the focus of papers considering individual nations has changed over the years. When such research began in the early 1990s most examined the efficiency of life insurers in the United States whereas in the late 1990s Germany became a larger focus. Starting in the mid 2000s Asian countries such as the PRC, the ROChina and India along with the United States became the spotlight of more life insurer efficiency studies than other nations. In addition various articles involving multiple nations, such as of Europe, of the Gulf Cooperation Council and worldwide have been performed, especially since the early 2000s. The number of papers of the most focused upon nations year-by-year (starting in 1992) are shown in Fig. 2 and Fig. 3 below: 


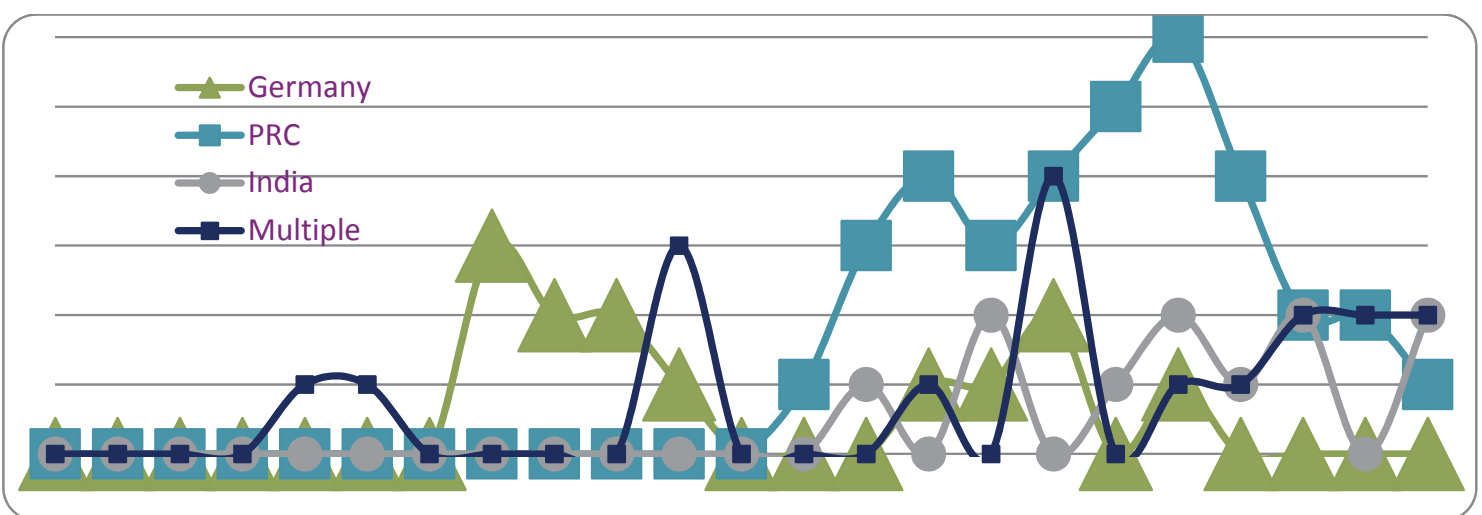

Three 2015 papers regarding India also in the survey

Fig. 2. Number of Life Insurance Efficiency Studies Regarding Germany, the PRC, India and Multiple Nations (Year-by-Year)

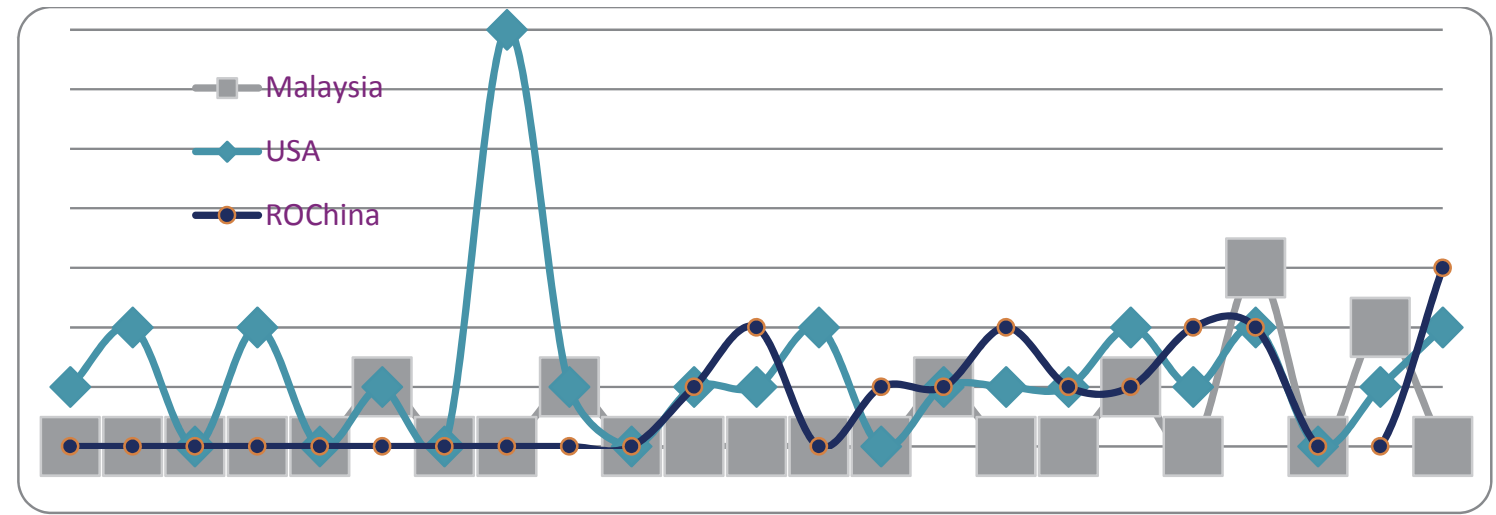

One 1986 paper regarding the USA and one 2015 paper regarding the ROChina also in the survey

Fig. 3. Number of Life Insurance Efficiency Studies Regarding Malaysia, the United States and the ROChina (Year-by-Year)

When taking multiple nation research into account, the United States, Germany the PRC and the ROChina are emphasized as above; however the United Kingdom, Italy and Spain replace India and Malaysia as the most explored nations. The number of studies of the most focused upon nations yearby-year (starting in 1992) are shown in Fig. 4 and Fig. 5 below:

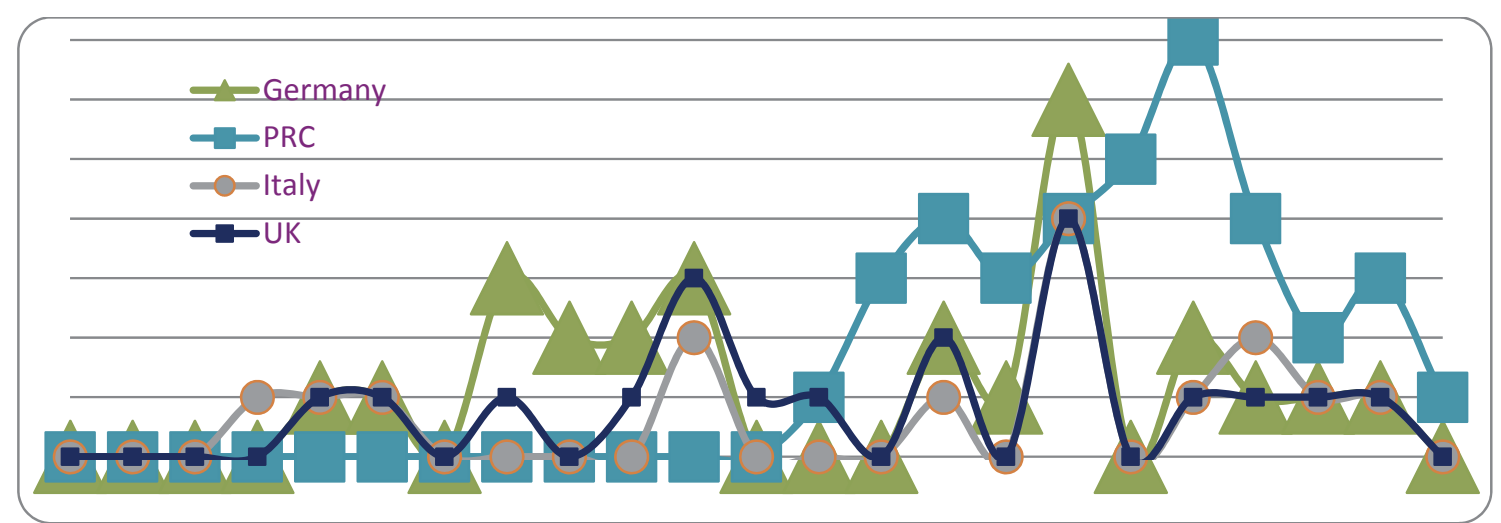

Fig. 4. Number of Life Insurance Efficiency Studies When Taking Multiple Nation Studies into Account Regarding Germany, the PRC, Italy and the UK (Year-by-Year) 


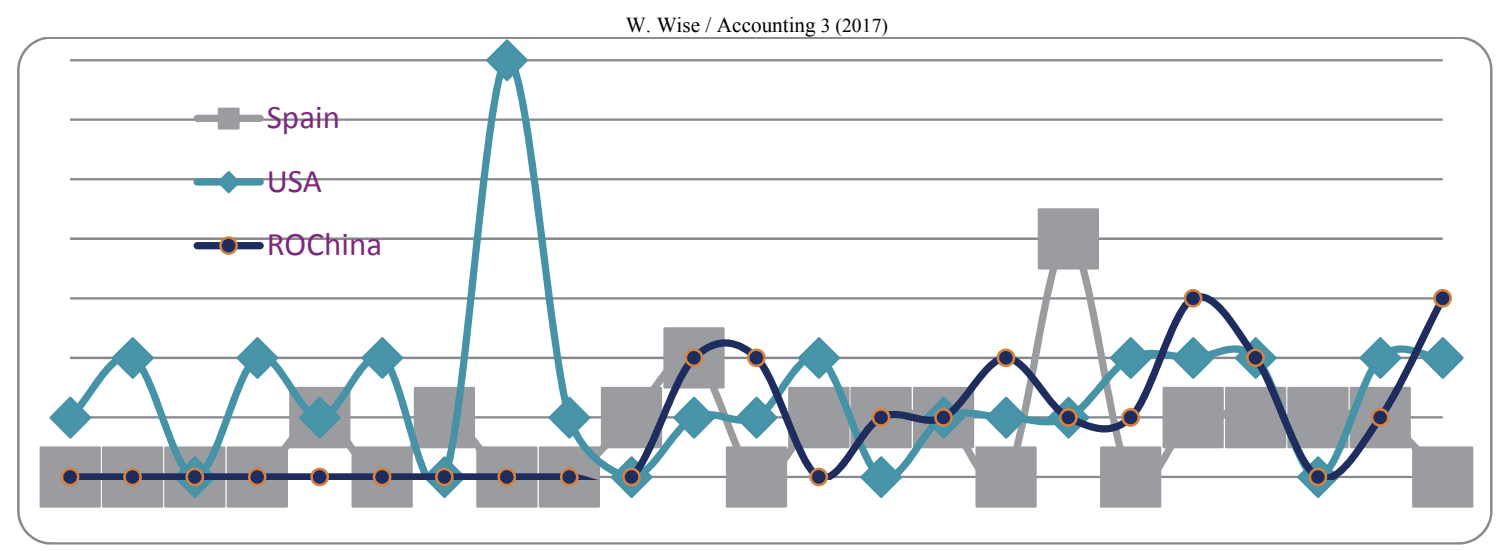

One 1986 paper regarding the USA and one 2015 paper regarding the ROChina also in the survey

Fig. 5. Number of Life Insurance Efficiency Studies When Taking Multiple Nation Studies into Account Regarding Spain, the United States and the ROChina (Year-by-Year)

The fact that, regarding life insurer efficiency, there has been a greater diversity of nations analyzed seems to indicate a greater awareness of its significance.

\subsection{Methods of Determining Efficiency}

Of the seven techniques listed above, when disallowing duplication of authors DEA is used in the greatest number of different papers, eighty-four. SFA is utilized in the next highest number, thirty-five different studies. Still disallowing author repetition two articles that incorporate SFA also employ FF as a semi-parametric method; five papers use DFA, two draw on FDH and one utilizes the Bayesian procedure. $^{5}$ No paper in the survey applies TFA. Eight items incorporate both SFA and DEA while for six studies this concept is not applicable. The counts of methods are shown in Table 1 below:

Table 1

Counts of methods of determining efficiency

\begin{tabular}{lll}
\hline Method & Number of Papers with no Author Duplication & Number of Papers \\
\hline DEA & 84 & 146 \\
SFA & $35(2$ use FF $)$ & $50(3$ use FF $)$ \\
DFA & 5 & 6 \\
FDH & 2 & 2 \\
Bayesian & 1 (uses SFA) & 1 (uses SFA) \\
TFA & 0 & 0 \\
N/A & 6 & 6 \\
\hline
\end{tabular}

When considering the number of papers both disallowing and with author duplication the trend has been that more have used DEA than SFA in almost all years. The number of studies utilizing the different methods of determining efficiency year-by-year (starting in 1992) are shown in Fig. 6 and Fig. 7 below:

\footnotetext{
${ }^{5}$ There is an overlap between the groups of authors. There are also overlaps between the groups of authors with respect to Tables 2, 3, 4, 5 and 6 .
} 


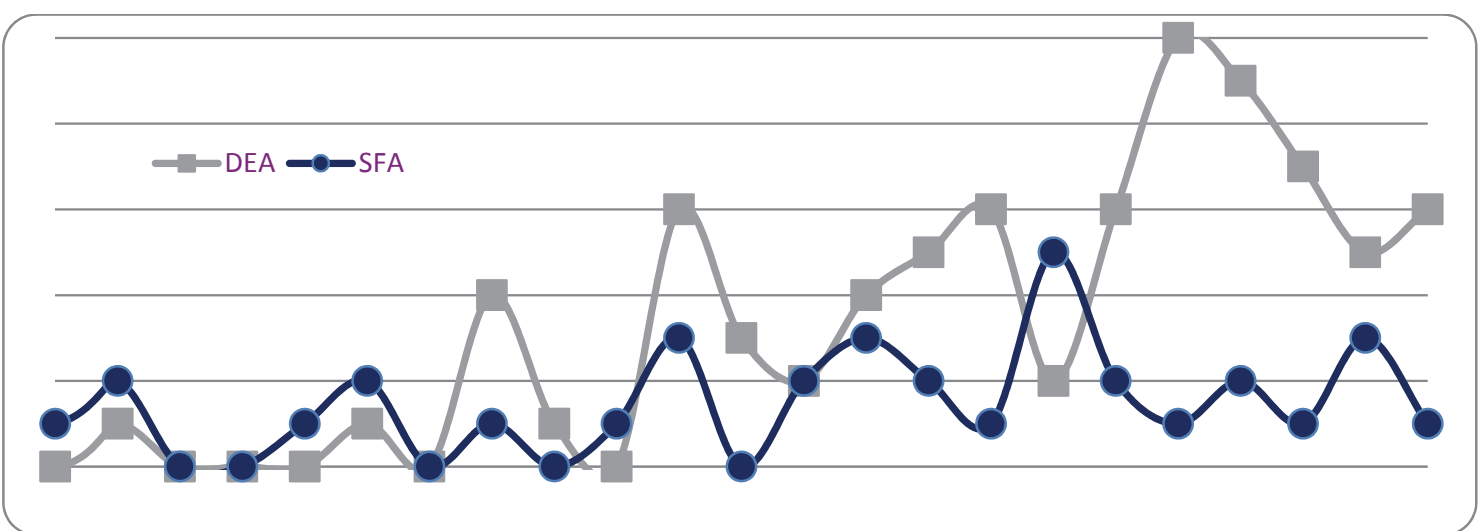

Five 2015 papers using DEA and one 2015 paper using SFA also in the survey

Fig. 6. Number of Life Insurance Efficiency Studies Using Different Methods of Determining Efficiency With no Author Duplication (Year-by-Year)

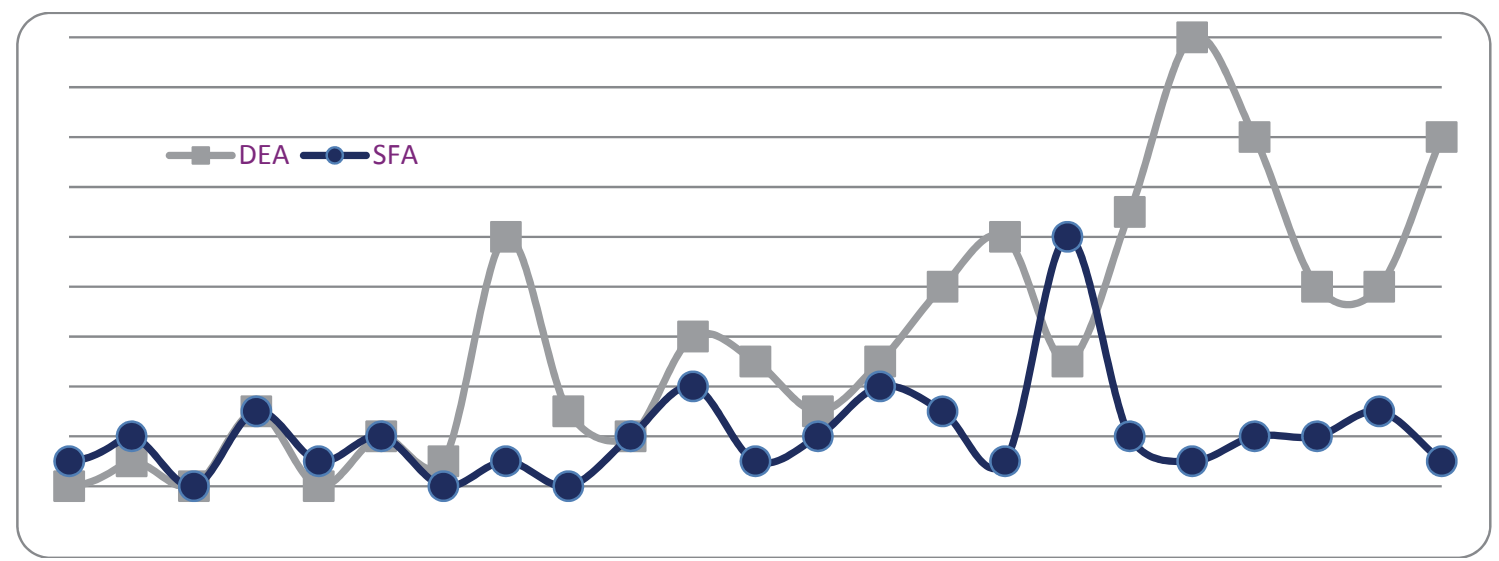

One 1986 paper using SFA, seven 2015 papers using DEA and one 2015 paper using SFA also in the survey

Fig. 7. Number of Life Insurance Efficiency Studies Using Different Methods of Determining Efficiency (Year-by-Year)

Of the eight papers that use both SFA and DEA, four illustrate a comparison of the efficiency scores by company characteristics such as company size and organizational form and three only show an overall inefficiency score obtained from the two methods. None of these papers show a company-bycompany comparison of efficiency scores.

Now, with respect to employing DEA there is an issue of whether enough DMUs (here insurance companies) are used versus the number of inputs and outputs. If the number of DMUs is low when compared to the number of inputs and outputs a high proportion will have an efficiency score of $100 \%$ as they will be difficult to match in all dimensions (Bauer et al., 1998; Thanassoulis et al., 2008). Dyson et al. (2001) notes that if incorporating DEA a study should have a number of DMUs that is at least as large as twice the product of the number of inputs and the number of outputs while Cooper et al. (2001) remarks that the number of DMUs should be at least three times the sum of said two numbers.

For the one hundred and forty-one papers utilizing DEA investigated as to the number of DMUs, inputs and outputs twenty-eight, about twenty percent, do not seem to have enough DMUs to have credibility. In addition a further nine, about six percent, seem questionable.

Related to the idea of using a parametric method is which functional form should be drawn upon to measure the efficient frontier. Common functional forms applied are the Cobb-Douglas, Box-Cox, translog and the Flexible Fourier (Sun \& Zhong, 2011) with others suggested being the Leontief and 
the quadratic (Caves \& Christensen, 1980). The choice of functional form implies the shape of the isoquants as well as the values of elasticities of factor demand and factor substitution (Greene, 2008). For example, with more than one output a Cobb-Douglas cost function can give rise to all of the possibility frontiers being convex instead of concave which implies only a few outputs being specialized by all DMUs (Greene, 2008). To avoid the above shortcoming flexible functional forms began to be utilized with the translog being the most common, perhaps as not very many confining assumptions concerning the technology are required by it (Kasman \& Turgutlu, 2009). Both the translog and the FF functional forms generate a large number of interaction terms and so potentially describe more of the deterministic relationships within the data than does the Cobb-Douglas (Ward, 2002). Even so, these functional forms have flaws such as not being monotonic or globally convex; both of which the Cobb-Douglas cost function exhibits (Greene, 2008) and that the interaction terms can result in a larger possibility of multicollinearity and so a corresponding lower capacity to know what causes costs or profits (Ward, 2002).

Within papers incorporating a parametric method, when disallowing duplication of authors a translog functional form is used in the greatest number of different studies, twenty-nine. Other methods are employed in only fourteen papers. It should be noted that some of the studies draw upon more than one method so the totals of the parametric methods in Table 1 above do not match the total number of papers here. The counts of functional forms are shown in Table 2 below:

\section{Table 2}

Counts of functional forms papers using a parametric method

\begin{tabular}{lll}
\hline Functional & $\begin{array}{l}\text { Number of Papers } \\
\text { with no Author Duplication }\end{array}$ & Number of Papers \\
\hline Translog & $29(2$ use FF $)$ & 41 (3 use FF) \\
Cobb-Douglas & 6 & 6 \\
Composite $^{\mathrm{a}}$ & 6 & 6 \\
Quadratic $_{\text {Other }}$ & 1 & 1 \\
\hline
\end{tabular}

a: Based on a Translog functional form.

\subsection{Output Proxy Sets}

For the efficiency studies of this survey investigated as to the output proxies, when disallowing duplication of authors a set of output proxies (akin to) premiums and investment income is utilized in sixty different studies. Output proxies (akin to) claims and (change in) reserves is employed in fifty different papers. Within the abovementioned sixteen studies draw upon both types of outputs. Four of these display the results when using each type of output proxy separately while the others apply a model that contains (part of) each type. There are seventeen papers for which the concept of output proxy sets is not applicable. The counts of output proxy sets are shown in Table 3 below:

Table 3

Counts of output proxy sets

\begin{tabular}{lll}
\hline Output Type & Number of Papers with no Author Duplication & Number of Papers \\
\hline $\begin{array}{l}\text { Premiums and Investment } \\
\text { Income }\end{array}$ & 60 & 90 \\
Claims and & & \\
(Change in) Reserves & 50 & 89 \\
Both (within the above) & 16 & 19 \\
N/A & 14 & 17 \\
\hline
\end{tabular}

When considering the number of studies without author duplication the recent trend has been that more have utilized a set of output proxies (akin to) premiums and investment income. By a count of papers 
there is no trend as to which set of output proxies is more prevalent. The number of studies incorporating the different sets of output proxies year-by-year (starting in 1992) are shown in Fig. 8 and Fig. 9 below:

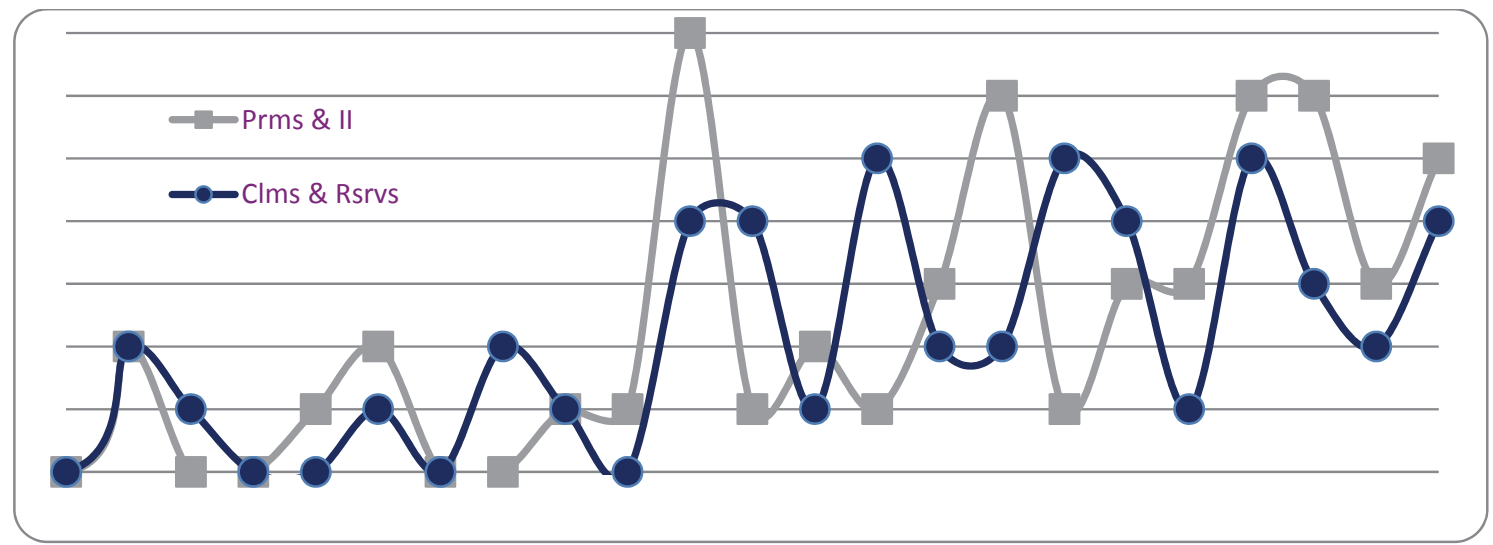

One 1983, one 1986 and three 2015 papers using Premiums \& II also in the survey One 2015 paper using Claims \& Reserves also in the survey

Fig. 8. Number of Life Insurance Efficiency Studies Using Different Output Proxy Sets With no Author Duplication (Year-by-Year)

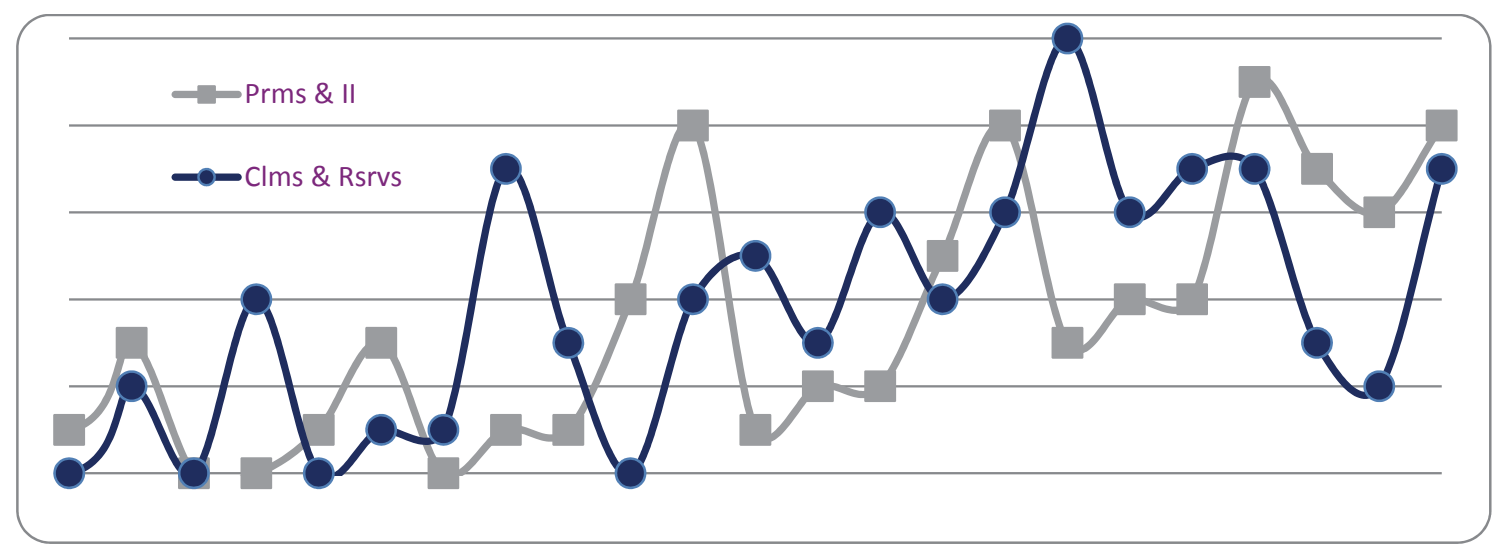

One 1983, one 1986 and five 2015 papers using Prms \& II also in the survey

One 2015 paper using Claims \& Reserves also in the survey

Fig. 9. Number of Life Insurance Efficiency Studies Using Different Output Proxy Sets (Year-by-Year)

Most papers using an output proxy (akin to) premiums employ only (earned) premiums. Some writers conclude that it is better not to employ such an output proxy but do so for various reasons. There are six such studies. Only a few papers use premiums combined with another measure. The counts of output proxies utilized in papers incorporating those (akin to) premiums are shown in Table 4 below:

Table 4

Counts of output proxies papers using premiums

\begin{tabular}{lll}
\hline & Number of Papers with no \\
Output Type & Author Duplication & Number of Papers \\
\hline Premiums Only & 48 & 72 \\
Earned Premiums $^{\text {a }}$ & 5 & 5 \\
Premiums \& Face Value & 2 & 2 \\
Number of Policies Only & 2 & 2 \\
Premiums \& Number of Policies & 2 & 2 \\
Number of Policies \& Face Value & 1 & 1 \\
Premiums \& Number of Policies \& Face Value & 3 & 3 \\
\hline
\end{tabular}

a: Six papers (five when disallowing author duplication) state that using premiums is inappropriate. 


\subsection{Form of Input Proxies}

One aspect of the inputs used in life insurance efficiency research is the form of the inputs. The two most prevalent forms are input prices and input monetary values. For the efficiency studies of this survey examined as to input proxies, when disallowing duplication of authors monetary values are used in the greatest number of different studies, fifty-three. Input prices are utilized in forty-two different papers. Fifteen studies incorporate quantities of inputs such as the number of employees, all but one in combination with monetary values. For six of the papers the concept is not applicable. The counts of input proxy forms used are shown in Table 5 below:

\section{Table 5}

Counts of input proxy forms

\begin{tabular}{lll}
\hline Input Type & Number of Papers with no Author Duplication & Number of Papers \\
\hline Prices & 42 & 80 \\
Monetary Values & 53 & 86 \\
Numbers/Quantities & 15 & 17 \\
N/A & 6 & 6 \\
\hline
\end{tabular}

When looking at the number of studies both without and with author duplication the trend has been that more have used input monetary values as an input proxy form more recently. The number of papers applying the different input proxy forms year-by-year (starting in 1992) are shown in Fig. 10 and Fig. 11 below:

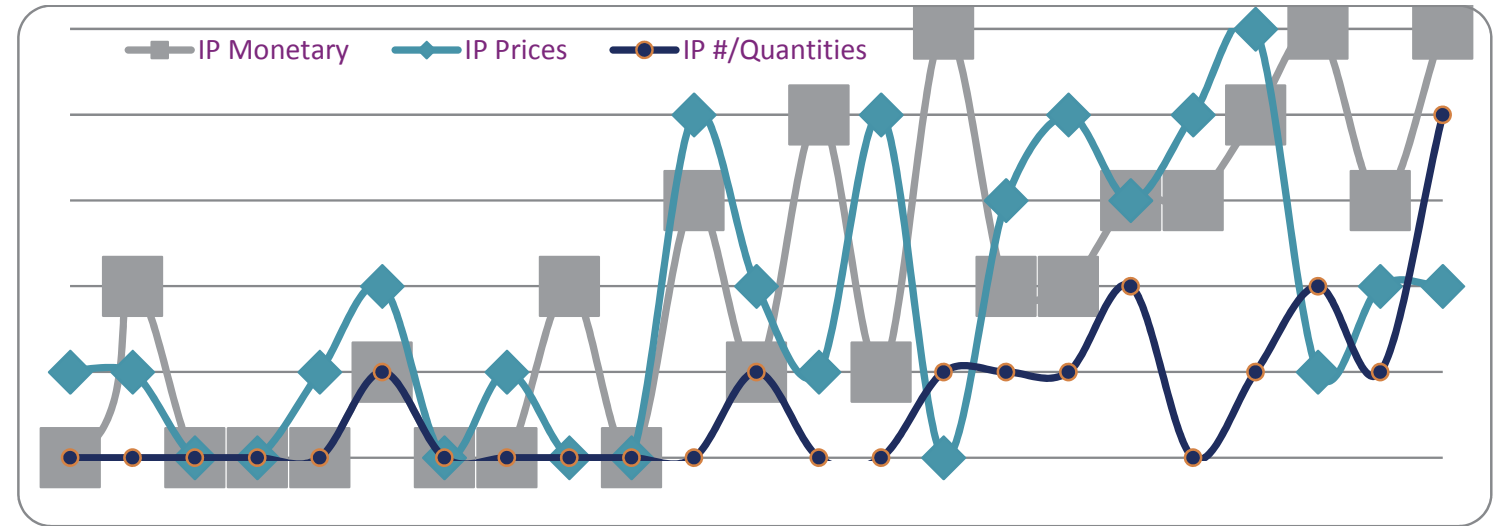

One 1983 paper using IP prices and IP monetary values and five 2015 papers using IP monetary values also in the survey

Fig. 10. Number of Life Insurance Efficiency Studies Using Different Input Proxy Forms With no Author Duplication (Year-by-Year)

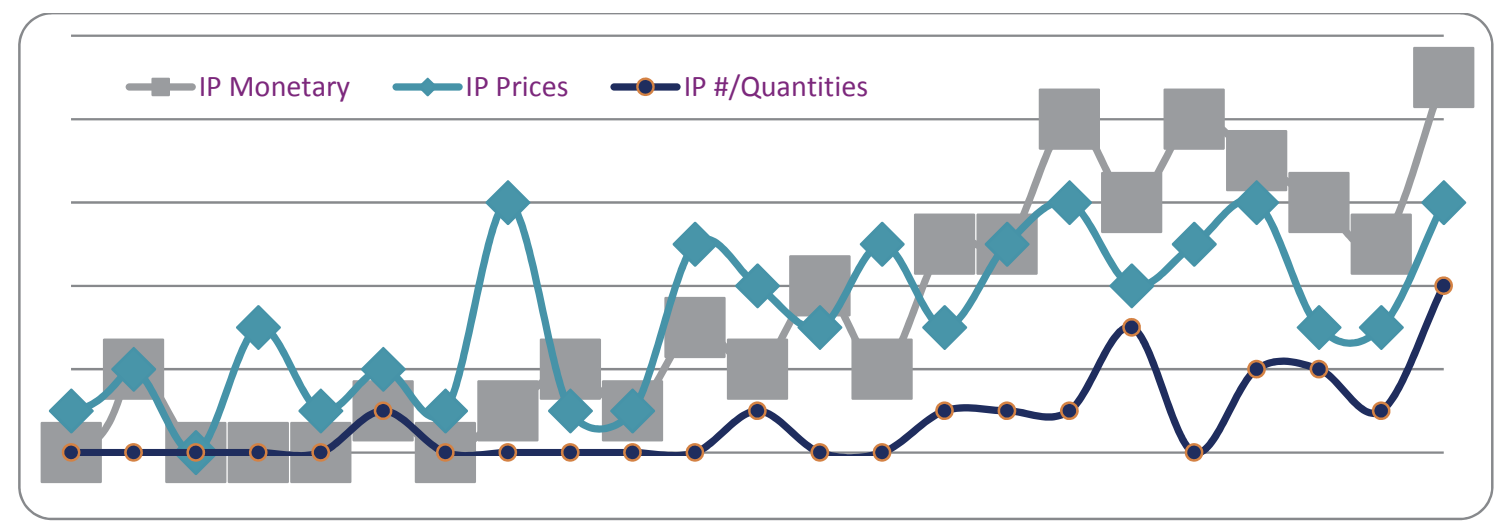

One 1983 paper using IP prices and IP monetary values, six 2015 papers using IP monetary values and one paper from each of 1986 and 2015 using IP prices also in the survey

Fig. 11. Number of Life Insurance Efficiency Studies Using Different Input Proxy Forms (Year-byYear) 
An important feature of life insurance efficiency studies utilizing input prices is the concept of drawing on such prices that are common (by year) across companies. In papers using input prices, when disallowing duplication of authors, prices that are totally common are incorporated in fifteen different studies. Input prices that are totally not common by year are utilized in fourteen different papers while input prices that are partly common and partly not are used in twenty different papers. The latter are labelled as Mixed in Table 6 below which shows the counts of commonality of input prices:

\section{Table 6}

Counts of input price commonality papers using input prices

\begin{tabular}{lll}
\hline & Number of Papers & \\
Price Commonality $^{\mathrm{a}}$ & with no Author Duplication & Number of Papers \\
\hline All Common & 15 & 33 \\
Mixed & 20 & 28 \\
All Not Common & 14 & 16 \\
\hline
\end{tabular}

a: For one paper using input prices the commonality is not extant.

When considering the research both without and with author duplication there has no trend as to whether the most studies have used common, not common or mixed input prices.

\section{Conclusions and Further Research}

This article has built upon previous studies such as Berger and Humphrey (1997), Cummins and Weiss (2000) and Eling and Luhnen (2010a) to enumerate and investigate the approaches most commonly drawn upon in over 190 papers to determine life insurance efficiency. This article has also described some of the advantages and disadvantages of these methods as well as explored the numbers and recent trends of approaches and some aspects of life insurance efficiency estimation.

There are many possible directions for further research in life insurance efficiency. Perhaps the most important possibility is that of profit efficiency. Only fifteen of the more than one hundred and ninety papers estimate profit efficiency with none written in 2015 or 2014 and only two written in 2013. Only six have been written since 2008. Profit efficiency might be seen as more important than cost efficiency for example Berger et al. (1993) states that profit efficiency may reduce problems associated with misspecification and mismeasurement" and it "allows the researcher to pinpoint better the sources of inefficiency." " Furthermore profit efficiency is more general than and includes cost efficiency (Akhavein et al., 1997, p. 96) and it may be that that "[i]n studying firm performance, profit maximization is superior to cost minimization" (Berger \& Mester, 2003, p. 67).

Another potential for further research is to investigate allocative efficiency in greater detail. Of the seventy-nine papers using input prices only twenty-six show allocative efficiency results, even though other studies state it is possible to calculate the allocative efficiency scores from their cost and technical efficiency scores. Perhaps allocative efficiency scores is being seen as more important as four of the papers that show allocative efficiency scores were written in 2014.

Further research can also be undertaken with respect to the functional forms used to determine life insurer efficiency. For example more of the papers that use both SFA and DEA can display the overall inefficiency scores as well as a company-by-company comparison calculated from the two methods. It also appears clear that more papers should employ both SFA and DEA and compare the results derived as it is possible that they will differ significantly. In addition more methods, such as DFA and FDH, might be used with comparisons of results.

\footnotetext{
${ }^{6}$ The emphasis is in the original.
} 
Similar comparisons might be made from the use of different functional forms when using parametric or semi-parametric methods as the results may also vary extensively. Furthermore such comparisons can be performed as to using the two basic sets of prevalent output proxies 1) reserves (or their change) and claims and 2) premiums and investment income.

Another prospect for further research is studies with a focus on developing markets. In addition an analysis of the trends mentioned above may help reveal which are the best directions to take further research.

As life insurance efficiency is an area gaining in recognition as being critical to analyze it can be important to both practitioners and regulators. Therefore those concerned with life insurance efficiency can possibly find this article useful as it will enable an assessment of which aspects of this field of study need more research and which are otherwise worth developing.

\section{References}

Adams, R. M., Berger, A. N., \& Sickles, R. C. (1999). Semiparametric approaches to stochastic panel frontiers with applications in the banking industry. Journal of Business \& Economic Statistics, 17(3), 349-358.

Afza, T. \& Jam-e-Kausar Ali Asghar, M. (2010). Efficiency of the Insurance Industry in Pakistan: An Application of Non-parametric Approach. Interdisciplinary Journal of Contemporary Research in Business, 2(8), 84-98.

Afza, T. \& Jam-e-Kausar Ali Asghar, M. (2012). Financial reforms and efficiency in the insurance companies of Pakistan. African Journal of Business Management, 6(30), 8957-8963.

Ahmad, W. M. A. W., Nawi, A. M. A. A., \& Aleng, N. A. (2013). Relative Efficiency Analysis Industry of Life and General Insurance in Malaysia Using Stochastic Frontier Analysis (SFA). Applied Mathematical Sciences, 7(23), 1107-1118.

Akhavein, J. D., Berger, A. N., \& Humphrey, D. B. (1997). The Effects of Megamergers on Efficiency and Prices: Evidence from a Bank Profit Function. Review of Industrial Organization, 12(1), 95139.

Al-Amri, K., Cummins, J. D. \& Weiss, M. A. (2014). Economies of Scope, Organizational Form, and Insolvency Risk: Evidence from the Takaful Insurance Industry (Fox School of Business Research Paper, \#15-050). Philadelphia, PA: Temple University.

Al-Amri, K., Gattoufi, S., \& Al-Muharrami, S. (2012). Analyzing the technical efficiency of insurance companies in GCC. The Journal of Risk Finance, 13(4), 362-380.

Alhassan, A. L. \& Addison, G. K. (2013, April). Market Structure, Efficiency and Performance: Empirical Evidence from the Ghanaian Life Insurance Market. Paper presented at the First University of Ghana Business School Conference and Development in Africa, Accra, Ghana held April 8-9, 2013.

Altunbas, Y. \& Chakravarty, S. P. (2001). Frontier cost functions and bank efficiency. Economics Letters, 72(2), 233-240.

Ansah-Adu, K., Andoh, C., \& Abor, J. (2012). Evaluating the cost efficiency of insurance companies in Ghana. The Journal of Risk Finance, 13(1), 61-76.

Aoba, N. (2006, August). Efficiency in the Japanese Life Insurance Industry: Dramatic Change. Paper presented at the American Risk and Insurance Association 2006 Annual Meeting, Washington, DC held August 6-9, 2006.

Asai, Y., Yanase, N., Tomimura, K. \& Ozeki, J. The Efficiency and Productivity of Life Insurance Industry in Japan.

Assaf, A., Barros, C. P., \& Josiassen, A. (2012). Hotel efficiency: A bootstrapped metafrontier approach. International Journal of Hospitality Management, 31(2), 621-629.

Atiquzzafar, K. \& Uzma, N. (2014). Efficiency measure of insurance v/s Takaful Firms using DEA approach: a case of Pakistan. Islamic Economic Studies, 22(1), 139-158. 
Australian Prudential Regulation Authority (APRA). (2015). Statistics: Life Insurance Institution-level Statistics. Retrieved from http://apra.gov.au/lifs/Publications/Pages/Life-Insurance-Institutionlevel-statistics.aspx. Canberra, ACT: APRA.

Avkiran, N. K. (Ed.). (2002). Productivity Analysis in the Service Sector: with Data Envelope Analysis. Camira (suburb of Brisbane), Qld: N. K. Avkiran.

Badunenko, O., Grechanyuk, B., \& Talavera, O. (2006). Development under regulation: The way of the Ukrainian insurance market (German Institute for Economic Research Discussion Paper 644). Berlin, Germany: DIW Berlin.

Banker, R. D. (1993). Maximum Likelihood, Consistency and Data Envelopment Analysis: A Statistical Foundation. Management Science, 39(10), 1265-1273.

Banker, R. D., Chang, H., \& Cooper, W. W. (2004). A simulation study of DEA and parametric frontier models in the presence of heteroscedasticity. European Journal of Operational Research, 153(3), 624-640.

Barnett, W., Geweke, J. \& Wolfe, M. (1991). Seminonparametric Bayesian estimation of consumer and factor demand models. In W. A. Barnett, B. Cornet, C. d'Aspermont, J. Gabszewicz \& A. Mas-Colell (Eds.), Equilibrium theory and applications: Proceedings of the sixth international symposium in economic theory and econometrics (pp. 425-480). Cambridge, UK: Cambridge University Press.

Barros, C. P., Barroso, N., \& Borges, M. R. (2005a). Evaluating the Efficiency and Productivity of Insurance Companies with a Malmquist Index: A Case Study for Portugal. The Geneva Papers on Risk and Insurance-Issues and Practice, 30(2), 244-267.

Barros, C. P., Barroso, N. \& Borges, M. R. (2005b, May/June). Measuring Efficiency in the Life Insurance Industry with a Stochastic Frontier Model. Paper presented at the 28th International Congress of Actuaries, Paris, France held May 28-June 2, 2006

Barros C. P., Caporale, G. M. \& Ibiwoye, A. (2008). A Two-stage efficiency analysis of the insurance industry in Nigeria. Department of Economics and Finance, Brunel University, London, UK, Working Paper 08-17.

Barros, C. P., Caporale, G. M., \& Ibiwoye, A. (2008). A two-stage efficiency analysis of the insurance industry in Nigeria. Uxbridge, UK: Centre for Empirical Finance (CEF).

Barros, C. P., Dumbo, S., \& Wanke, P. (2014). Efficiency Determinants and Capacity Issues in Angolan Insurance Companies. South African Journal of Economics, 82(3), 455-467.

Barros, C. P., Nektarios, M., \& Assaf, A. (2010). Efficiency in the Greek insurance industry. European Journal of Operational Research, 205(2), 431-436.

Barros, C. P. \& Obijiaku, E. L. (2007). Technical Efficiency of Nigerian Insurance Companies (School of Economics and Management Working Paper 018/2007/DE/UECE). Lisbon, Portugal: Technical University of Lisbon.

Bauer, P. W., Berger, A. N., Ferrier, G. D., \& Humphrey, D. B. (1998). Consistency Conditions for Regulatory Analysis of Financial Institutions: A Comparison of Frontier Efficiency Methods. Journal of Economics and Business, 50(2), 85-114.

Berger, A. N. (1993). "Distribution-free" estimates of efficiency in the US banking industry and tests of the standard distributional assumptions. Journal of Productivity Analysis, 4(3), 261-292.

Berger, A. N., Cummins, J. D., \& Weiss, M. A. (1997). The Coexistence of Multiple Distribution Systems for Financial Services: The Case of Property-Liability Insurance. The Journal of Business, 70(4), 515-546.

Berger, A. N., Cummins, J. D., Weiss, M. A., \& Zi, H. (2000). Conglomeration versus Strategic Focus: Evidence from the Insurance Industry. Journal of Financial Intermediation, 9(4), 323-362.

Berger, A. N., Hancock, D., \& Humphrey, D. B. (1993). Bank efficiency derived from the profit function. Journal of Banking \& Finance, 17(2-3), 317-347.

Berger, A. N., \& Humphrey, D. B. (1991). The dominance of inefficiencies over scale and product mix economies in banking. Journal of Monetary Economics, 28(1), 117-148.

Berger, A. N. \& Humphrey, D. B. (1992). Measurement and Efficiency Issues in Commercial Banking. In Z. Griliches (Ed.), Output Measurement in the Service Sectors, National Bureau of Economic 
Research, Studies in Income and Wealth, Volume 56. Chicago, IL: University of Chicago Press. Retrieved from http://www.nber.org/chapters/c7237.pdf

Berger, A. N., \& Humphrey, D. B. (1997). Efficiency of Financial Institutions: International Survey and Directions for Future Research. European Journal of Operational Research, 98(2), 175-212.

Berger, A. N., \& Mester, L. J. (1997). Inside the black box: What explains differences in the efficiencies of financial institutions? Journal of Banking \& Finance, 21(7), 895-947.

Berger, A. N., \& Mester, L. J. (2003). Explaining the dramatic changes in performance of US banks: technological change, deregulation, and dynamic changes in competition. Journal of Financial Intermediation, 12(1), 57-95.

Bernier, G. \& Sedzro, K. (2003, August). An Intertemporal Analysis of Efficiency Using DEA: The Case of the Canadian Life Insurance Industry Prior to 2000. Paper presented at the American Risk and Insurance Association 2003 Annual Meeting, Denver, CO held August 10-13, 2003.

Bernstein, J. I. (1998). Total Factor Productivity Growth in the Canadian Life Insurance Industry: 1979-1989 (National Bureau of Economic Research (NBER) Working Paper 6475). Cambridge (suburb of the Boston-Worcester-Providence CSA), MA: NBER.

Biener, C., \& Eling, M. (2012). Organization and efficiency in the international insurance industry: A cross-frontier analysis. European Journal of Operational Research, 221(2), 454-468.

Biener, C., Eling, M. \& Wirfs, J. H. (2014, September). The Determinants of Efficiency and Productivity in the Swiss Insurance Industry. Paper presented at the 41st Seminar of the European Group of Risk and Insurance Economists, St. Gallen, Switzerland held September 15-17, 2014.

Bikker, J. A. (2012). Performance of the life insurance industry under pressure: efficiency, competition and consolidation (Working Paper No. 357). Amsterdam, The Netherlands: De Nederlandsche Bank NV.

Bikker, J. A., \& van Leuvensteijn, M. (2008). Competition and Efficiency in the Dutch Life Insurance Industry. Applied Economics, 40(16), 2063-2084.

Blair, R. D., Jackson, J. R., \& Vogel, R. J. (1975). Economies of scale in the administration of health insurance. The Review of Economics and Statistics, 57(2), 185-189.

Boonyasai, T. The Effect of liberalization on Thai life insurer efficiency. Symposium of Chulalongkorn University, Bangkok, Thailand.

Boonyasai, T., Grace, M. F. \& Skipper, Jr., H. D. (2002). The Effect of Liberalization and Deregulation on Life Insurer Efficiency (Center for Risk Management and Insurance Research Working Paper No. 02-2). Atlanta, GA: Georgia State University.

Borges, M. R., Nektarios, M., \& Barros, C. P. (2008). Analysing The Efficiency Of The Greek Life Insurance Industry. European Research Studies, 11(3), 35-52.

Brockett, P. L., Chang, R. E., Rousseau, J. J., Semple, J. H., \& Yang, C. (2004). A Comparison of HMO Efficiencies as a Function of Provider Autonomy. Journal of Risk and Insurance, 71(1), 119.

Brockett, P. L., Cooper, W. W., Golden, L. L., Rousseau, J. J., \& Wang, Y. (2005). Financial Intermediary versus Production Approach to Efficiency of Marketing Distribution Systems and Organizational Structure of Insurance Companies. Journal of Risk and Insurance, 72(3), 393-412.

Cabanda, E. \& Viverita, D. (2012). Managerial efficiency, innovation, and productivity of the Indonesian life insurance industry during the global financial crisis. Journal of International Business and Economics, 12(5), 32-39.

Cao, Q. (2006). Efficiency Evolution of Chinese Insurance Industry: A Study Based on DEA and MI Models. Journal of Guangdong University of Finance, 21(5), 69-74.

Carr, R. M., Cummins, J. D. \& Regan, L. (1999). Efficiency and competitiveness in the US life insurance industry: corporate, product, and distribution strategies. In J. D. Cummins \& A. M. Santomero (Eds.), Changes in the Life Insurance Industry: Efficiency, Technology and Risk Management (pp. 117-158). Norwell (suburb of the Boston-Worcester-Providence CSA), MA: Kluwer Academic Publishers.

Caves, D. W., \& Christensen, L. R. (1980). Global Properties of Flexible Functional Forms. The American Economic Review, 70(3), 422-432. 
Chadwick, C. \& Cappelli, P. (1999). Strategy, Human Resource Management, and the Performance of Life Insurance Firms. In J. D. Cummins \& A. M. Santomero (Eds.), Changes in the Life Insurance Industry: Efficiency, Technology and Risk Management (pp. 187-210). Norwell (suburb of the Boston-Worcester-Providence CSA), MA: Kluwer Academic Publishers.

Chaffai, M. E. \& Ouertani, M. N. (2002). Technical efficiency in the Tunisian insurance industry: A comparison of parametric and non parametric time variant models (Research Unit on Production Econometrics Working Paper). Sfax, Tunisia: Sfax University.

Chakraborty, J. \& Sengupta, P. P. (2012). Measuring Performance and Efficiency Growth of the Selected Indian Life Insurance Companies: A Total Factor Productivity Approach. Arth Prabhand: A Journal of Economics and Management, 1(6), 1-20.

Charnes, A., Cooper, W. W., \& Rhodes, E. (1978). Measuring the efficiency of decision making units. European Journal of Operational Research, 2(6), 429-444.

Chen, B., Powers, M. R., \& Qiu, J. (2008). Development of the Chinese life insurance industry: An efficiency analysis. The Capco Institute: Journal of Financial Transformation, 22, 123-130.

Chen, B., Powers, M. R., \& Qiu, J. (2009). Life-insurance Efficiency in China: A Comparison of Foreign and Domestic Firms. China \& World Economy, 17(6), 43-63.

Chen, L. (2005). An Analysis of Malmquist Index: Efficiency of Insurance Industry in China. Modern Economic Science, 27(5), 39-44.

Chen, L., Eckles, D. L., \& Pottier, S. W. (2013). Ownership Form and Efficiency: The Coexistence of Stock and Mutual Life Insurers. The Journal of Insurance Issues, 36(2), 121-148.

Chen, L. R., \& McNamara, M. J. (2014). An Examination of the Relative Efficiency of Fraternal Insurers. The Journal of Insurance Issues, 37(1), 1-31.

Chen, M. S., \& Chang, P. L. (2010). Distribution channel strategy and efficiency performance of the life insurance industry in Taiwan. Journal of Financial Services Marketing, 15(1), 62-75.

Chiang, K. F. \& Cheng, S. W. (2009). An efficiency comparison of direct and indirect channels in Taiwan insurance marketing. Direct Marketing: An International Journal, 3(4), 343-359.

Chuang, C. C., \& Tang, Y. C. (2014). Asymmetric Dependence between Efficiency and Market Power: Longitudinal Perspective of the Taiwan Life Insurance Industry. International Journal of Applied Mathematics and Statistics, 52(8), 144-151.

Coelli, T. J., Rao, D. S. P., O’Donnell, C. J. \& Battese, G. E. (2005). An Introduction to Efficiency and Productivity Analysis (2nd ed.). New York, NY: Springer Science+Business Media, Incorporated.

Cooper, W. W., Li, S., Seiford, L. M., Thrall, R. M. \& Zhu, J. (2001). Sensitivity and stability analysis in DEA: Some recent developments. Journal of Productivity Analysis, 15(3), 217-246.

Cooper, W. W., Park, K. S., \& Pastor, J. T. (1999). RAM: a range adjusted measure of inefficiency for use with additive models, and relations to other models and measures in DEA. Journal of Productivity Analysis, 11(1), 5-42.

Cummins, J. D. (1999). Efficiency in the US life insurance industry: Are insurers minimizing costs and maximizing revenues? In J. D. Cummins \& A. M. Santomero (Eds.), Changes in the Life Insurance Industry: Efficiency, Technology and Risk Management (pp. 75-116). Norwell (suburb of the Boston-Worcester-Providence CSA), MA: Kluwer Academic Publishers.

Cummins, J. D., Eckles, D. L., \& Zi, H. (2006). Exporting best practices: Are foreign-owned insurers more efficient in the US Life Insurance Market? Working paper.

Cummins, J. D. \& Rubio-Misas, M. (2001). Deregulation, Consolidation and Efficiency: Evidence From the Spanish Insurance Industry (The Wharton Financial Institutions Center Working Paper 02-01). Philadelphia, PA: University of Pennsylvania.

Cummins, J. D., Rubio-Misas, M., \& Zi, H. (2004). The effect of organizational structure on efficiency: Evidence from the Spanish insurance industry. Journal of Banking \& Finance, 28(12), 3113-3150.

Cummins, J. D., Tennyson, S., \& Weiss, M. A. (1999a). Consolidation and efficiency in the US life insurance industry. Journal of Banking \& Finance, 23(2-4), 325-357.

Cummins, J. D., Tennyson, S. \& Weiss, M. A. (1999b). Life insurance mergers and acquisitions. In J. D. Cummins \& A. M. Santomero (Eds.), Changes in the Life Insurance Industry: Efficiency, 
Technology and Risk Management (pp. 159-186). Norwell (suburb of the Boston-WorcesterProvidence CSA), MA: Kluwer Academic Publishers.

Cummins, J. D., Turchetti, G. \& Weiss, M. A. (1996). Productivity and Technical Efficiency in the Italian Insurance Industry (The Wharton Financial Institutions Center Working Paper 96-10). Philadelphia, PA: University of Pennsylvania.

Cummins, J. D. \& Weiss, M. A. (2000). Analyzing Firm Performance in the Insurance Industry Using Frontier Efficiency and Productivity Methods. In H. G. Dionne, (Ed.), Handbook of Insurance (pp. 767-829). Norwell (suburb of the Boston-Worcester-Providence CSA), MA: Kluwer Academic Publishers.

Cummins, J. D., Weiss, M. A., Xie, X., \& Zi, H. (2010). Economies of scope in financial services: A DEA efficiency analysis of the US insurance industry. Journal of Banking \& Finance, 34(7), 15251539.

Cummins, J. D., Weiss, M. A. \& Zi, H. (2003, September). Economies of Scope in Financial Services: A DEA Bootstrapping Analysis of the US Insurance Industry. Paper presented at the 4th International Symposium on DEA, Birmingham, UK held September 4-6, 2004.

Cummins, J. D., \& Xie, X. (2009). Market values and efficiency in US insurer acquisitions and divestitures. Managerial Finance, 35(2), 128-155.

Cummins, J. D. \& Zi, H. (1997). Measuring Cost Efficiency in the U.S. Life Insurance Industry: Econometric and Mathematical Programming Approaches (The Wharton Financial Institutions Center Working Paper 97-03). Philadelphia, PA: University of Pennsylvania.

Cummins, J. D., \& Zi, H. (1998). Comparison of Frontier Efficiency Models: An Application to the U. S. Life Insurance Industry. Journal of Productivity Analysis, 10(2), 131-152.

Dalkiliç, N., \& Ada, A. A. (2014). Efficiencies of Life/Pension Insurance Industry in Turkey: An Application of Data Envelopment Analysis Journal of Applied Finance and Banking, 4(1), 181-191.

Davutyan, N. \& Klumpes, P. J. M. (2008, July). Consolidation and Efficiency in the Major European Insurance Markets: A Non Discretionary Inputs Approach. Paper presented at a conference on the Uses of Frontier Efficiency Methodologies for Performance Measurement in the Financial Services Sector, Imperial College Business School, London, UK held July 4-5, 2008.

De Luca Cardillo, D. \& Fortuna, T. (2000). A DEA model for the efficiency evaluation of nondominated paths on a road network. European Journal of Operational Research, 121(3), 549558.

Deng, Y. (2010). The Efficiency Analysis of the Life Insurance Industry in China-Based on the DEA Method (Unpublished Master's thesis). The University of Texas at Austin, Austin (suburb of the Austin-Round Rock CSA), TX.

Deprins, D., Simar, L. \& Tulkens, H. (1984). Measuring labor-efficiency in post offices. In M. Marchand, P. Pestieau \& H. Tulkens (Eds.), The performance of public enterprises: Concepts and measurement (pp. 243-267). Amsterdam, Netherlands: Elsevier Science Publishers.

Diacon, S. R., Starkey, K. \& O’Brien, C. (2002). Size and Efficiency in European Long-term Insurance Companies: An International Comparison. The Geneva Papers on Risk and Insurance-Issues and Practice, 27(3), 444-466.

Diewert, W.E. (1995). Functional form problems in modeling insurance and gambling. The Geneva Papers on Risk and Insurance-Theory, 20(1), 135-150.

Donni, O. \& Fecher, F. (1997). Efficiency and Productivity of the Insurance Industry in the OECD Countries. The Geneva Papers on Risk and Insurance-Issues \& Practice, 22(4), 523-535.

Donni, O. \& Hamende, V. (1993). Performance des Societies Belges D'Assurance: Comparaison des formes institutionnelles. Annals of Public and Cooperative Economics, 64(3), 419-438.

Drake, L., Hall, M. J. B. \& Simper, R. (2006). The impact of macroeconomic and regulatory factors on bank efficiency: A non-parametric analysis of Hong Kong's banking system. Journal of Banking \& Finance, 30(5), 1443-1466.

Dutta, A. \& Sengupta, P. P. (2010, November). Impact of Technological Innovation on Efficiency - An Empirical Study of Indian Life Insurance Industry. Paper presented at the 2010 International Conference on Education and Management Technology, Cairo, Egypt held November 2-4, 2010. 
Dutta, A. \& Sengupta, P. P. (2011). Efficiency Measurement of Indian Life Insurance Industry in PostReforms Era. Global Business Review, 12(3), 415-30.

Dyson, R. G., Allen, R., Camanho, A. S., Podinovski, V. V., Sarrico, C. S. \& Shale, E. A. (2001). Pitfalls and protocols in DEA. European Journal of Operational Research, 132(2), 245-259.

Efron, B. (1979). Bootstrap Methods: Another Look at the Jackknife. The Annals of Statistics, 7(1), 126

Eling, M. \& Luhnen, M. (2010a). Frontier efficiency methodologies to measure performance in the insurance industry: Overview, systemization and recent developments. The Geneva Papers on Risk and Insurance-Issues \& Practice, 35(2), 217-265.

Eling, M. \& Luhnen, M. (2010b). Efficiency in the international insurance industry: A cross-country comparison. Journal of Banking \& Finance, 34(7), 1497-1509.

Ennsfellner, K. C., Lewis, D. \& Anderson, R. I. (2004). Production Efficiency in the Austrian Insurance Industry: A Bayesian Examination. Journal of Risk and Insurance, 71(1), 135-159.

Erhemjamts, O. \& Leverty, J. T. (2010). The Demise of the Mutual Organizational Form: An Investigation of the Life Insurance Industry. Journal of Money, Credit and Banking, 42(6), 10111036.

Fan, Y., Li, Q. \& Weersink, A. (1996). Semiparametric Estimation of Stochastic Production Frontier Models. Journal of Business \& Economic Statistics, 14(4), 460-468.

Fare, R. Grosskopf, S. \& Knox Lovell, C. A. (1994). Production Frontiers. Cambridge, U.K.: Cambridge University Press.

Faruk, O. \& Rahaman, A. (2015). Measuring Efficiency of Conventional Life Insurance Companies in Bangladesh and Takaful Life Insurance Companies in Malaysia: A Non-Parametric Approach. Management Studies and Economic Systems, 2(2), 129-44.

Fecher, F., Kessler, D., Perelman, S. \& Pestieau, P. (1993). Productive performance of the French Insurance Industry. Journal of Productivity Analysis, 4(1/2), 77-93.

Fenn, P., Vencappa, D., Diacon, S. R., Klumpes, P. J. M. \& O’Brien, C. (2008). Market structure and the efficiency of European insurance companies: A stochastic frontier analysis. Journal of Banking \& Finance, 32(1), 86-100.

Fiordelisi, F. \& Ricci, O. (2011). Bancassurance efficiency gains: evidence from the Italian banking and insurance industries. The European Journal of Finance, 17(9-10), 789-810.

Fuentes, H., Grifell-Tatjé, E. \& Perelman, S. (2001). A Parametric Distance Function Approach for Malmquist Productivity Index Estimation. Journal of Productivity Analysis, 15(2), 79-94.

Fuentes, H., Grifell-Tatjé, E. \& Perelman, S. (2005). Product Specialization, Efficiency and Productivity Change in the Spanish Insurance Industry (Centre de Recherche en Economie Publique et de la Population (Research Center on Public and Population Economics) HEC-Management School Working Paper 0506). Liege, Belgium: University of Liege.

Fukuyama, H. (1997). Investigating productive efficiency and productivity changes of Japanese life insurance companies. Pacific-Basin Finance Journal, 5(4), 481-509.

Gaganis, C., Hasan, I. \& Pasiouras, F. (2013). Efficiency and stock returns: evidence from the insurance industry. Journal of Productivity Analysis, 40(3), 429-442.

Gallant, A. R. \& Golub, G. H. (1982). Imposing Curvature Restrictions on Flexible Functional Forms (Kellogg School of Management Discussion paper No. 538). Evanston (suburb of the ChicagoNaperville CSA), IL: Northwestern University.

Gan, Q., \& Hu, S. (2007). Operating Efficiency of Life- Health Insurance Industry and Contribution of Bancassurance. Finance \& Economics, 2007(9), 32-36.

Gardner, L. A. \& Grace, M. F. (1993). X-Efficiency in the US life insurance industry. Journal of Banking \& Finance, 17(2-3), 497-510.

Grace, M. F. \& Timme, S. G. (1992). An Examination of Cost Economies in the United States Life Insurance Industry. Journal of Risk and Insurance, 59(1), 72-103.

Greene, W. H. (1990). A Gamma Distributed Stochastic Frontier Model. Journal of Econometrics, 46(1-2), 141-163. 
Greene, W. H. (2008). The Econometric Approach to Efficiency Analysis. In H. O. Fried, C. A. Knox Lovell \& S. S. Schmidt (Eds.), The Measurement of Productive Efficiency and Productivity Growth (pp. 92-250). New York, NY: Oxford University Press.

Greene, W. H. \& Segal, D. (2004). Profitability and Efficiency in the U.S. Life Insurance Industry. Journal of Productivity Analysis, 21(3), 229-247.

Han, S. \& Wang, D-L. (2009). Efficiency analysis on Chinese insurance industry: 2003-2007. Insurance Studies, 2009(6), 20-28.

Hao, J. C. (2003, August). X-Efficiency in the Taiwan Life Insurance Industry. Paper presented at the American Risk and Insurance Association 2003 Annual Meeting, Denver, CO held August 10-13, 2003.

Hao, J. C. (2005, August). Comparison of Efficiency Estimation Models - The Case in Taiwan's Life Insurance Industry. Paper presented at the World Risk and Insurance Economics Congress Inaugural Meeting, Salt Lake City, UT held August 7-11, 2005.

Hao, J. C. (2008). Measuring Cost Efficiency in the Taiwan Life Insurance Industry. International Journal of Management, 25(2), 279-286.

Hardwick, P. (1997). Measuring cost efficiency in the UK life insurance industry. Applied Financial Economics, 7(1), 37-44.

Hardwick, P., Adams, M. B. \& Zou, H. (2003). Corporate Governance and Cost Efficiency in the United Kingdom Life Insurance Industry (European Business Management School Working Paper No. EBMS/2003/1). Swansea, UK: EBMS.

Hitt, L. M. (1999). The impact of information technology management practices on the performance of life insurance companies. In J. D. Cummins \& A. M. Santomero (Eds.), Changes in the Life Insurance Industry: Efficiency, Technology and Risk Management (pp. 211-244). Norwell (suburb of the Boston-Worcester-Providence CSA), MA: Kluwer Academic Publishers.

Hjalmarsson, L., Kumbhakar, S. C. \& Heshmati, A. (1996). DEA, DFA and SFA: A Comparison. The Journal of Productivity Analysis, 7(2/3), 303-327.

Hong, W. (2010). Development Path of Small-and-Medium-sized Insurance Companies in China Based on Efficiency and Total Factor Productivity, Journal of Xidian University (Social Science Edition), 20(1), 58-63.

$\mathrm{Hu}$, X., Zhang, C., Hu, J-L. \& Zhu, N. (2009). Analyzing efficiency in the Chinese life insurance industry. Management Research News, 32(10), 905-920.

Huang, L-Y., Hsiao, T-Y. \& Lai, G. C. (2007). Does Corporate Governance and Ownership Structure Influence Performance? Evidence from Taiwan Life Insurance Companies. Journal of Insurance Issues, 30(2), 123-151.

Huang, T-H., Kao, T-L., Chiang, L-C. \& Liang, J-H. (2010). A Study of Technical Efficiency and Productivity Change on Taiwan's Life Insurance Companies with Quasi-fixed Inputs. Soochow Journal of Economics and Business, 68, 1-38.

Huang, W. (2006). Efficiency of China's Insurance Industry: A Stochastic Frontier Analysis Approach. Nankai Economic Studies, 2006(5), 104-115.

Huang, W. (2007, August). Efficiency in the China Insurance Industry: 1999-2004. Paper presented at the American Risk and Insurance Association 2007 Annual Meeting, Québec City, QC held August 4-7, 2007.

Huang, W. (2008). Risk-Adjusted Efficiency Analysis of the Chinese Insurance Companies. Collected Essays on Finance and Economics, 2008(5), 63-68.

Huang, W. (2008). Risk-Adjusted Efficiency Analysis of the Chinese Insurance Industry: A Stochastic Frontier Approach. The Journal of Quantitative \& Technical Economics, 2008(12), 111-23.

Huang, W. \& Yang, F. (2012). On the Marketing Efficiency Evaluation of the Chinese Life Insurance Industry. Journal of Financial Research, 2012(2), 113-126.

Hussels, S. \& Ward, D. R. (2004). Cost Efficiency and Total Factor Productivity in the European Life Insurance Industry: The Development of the German Life Insurance Industry Over the Years 19912002 (School of Management Working Paper No. 04/05). Bradford, UK: University of Bradford. 
Hussels, S. \& Ward, D. R. (2006, May). The Impact of Deregulation on the German and UK Life Insurance Markets: An Analysis of Efficiency and Productivity Between 1991-2002. Paper presented at the Dynamics of Insurance Markets: Structure, Conduct, and Performance in the 21 st Century, A Journal of Banking and Finance Conference, Wharton School, University of Pennsylvania, Philadelphia, PA held May 4-5, 2006.

Hwang, T. \& Gao, S. S. (2005). An empirical study of cost efficiency in the Irish life insurance industry. International Journal of Accounting, Auditing and Performance Evaluation, 2(3), 264-280.

Islam, J., Rahman, A. \& Bhuiyan, Z. H. (2013). Measures of Efficiency in the Takaful Industry of Bangladesh - A Non-Parametric Approach. Islamic Management and Business, 5(11), 163-73.

Ismail, N., Alhabshi, D. S. O. \& Bacha, O. I. (2011). Organizational Form and Efficiency: The Coexistence of Family Takaful and Life Insurance in Malaysia. Journal of Global Business and Economics, 3(1), 122-137

Ismail, N., Alhabshi, D. S. O. \& Bacha, O. I. (2013, June). Cost Efficiency and Investment Performance: Mutual and Stock Form in Malaysian Insurance Industry. Paper presented at the 15th Malaysian Finance Association Conference, International Centre for Education in Islamic Finance, Kuala Lumpur, Malaysia held June 2-4, 2013.

Jarraya, B. \& Bouri, A. (2012). Efficiency concept and investigations in insurance industry: A survey. Management Science Letters, 3(1), 39-54.

Jeng, V., Lai, G. C. \& McNamara, M. J. (2007). Efficiency and Demutualization: Evidence from the U.S. Life Insurance Industry in the 1980s and 1990s. The Journal of Risk and Insurance, 74(3), 683711.

Kao, C. (2009). Efficiency decomposition in network data envelopment analysis: A relational model. European Journal of Operational Research, 192(3), 949-962.

Karim, M. \& Jhantasana, C. (2005). Cost Efficiency and Profitability in Thailand's Life Insurance Industry: A Stochastic Cost Frontier Approach. International Journal of Applied Econometrics and Quantitative Studies, 2(4), 19-36.

Kasman, A. \& Turgutlu, E. (2009). Cost efficiency and scale economies in the Turkish insurance industry. Applied Economics, 41(24), 3151-3159.

Kaur, L. (2015). Performance Evaluation of Life Insurance Companies: A Study of Pre \& Post-Reforms Period (Unpublished doctoral dissertation). Punjabi University, Patiala, India.

Kellner, S. \& Mathewson, G. F. (1983). Entry, Size Distribution, Scale, and Scope Economies in the Life Insurance Industry. The Journal of Business, 56(1), 25-44.

Kessner, K. (2001a). Ein Effizienzvergleich deutscher und britischer Lebensversicherungen. In: Markttransparenz und Produktionseffizienz in der deutschen Lebensversicherung. Munich, Germany: Ludwig- Maximilians University.

Kessner, K. (2001b). Skaleneffizienz und Produktivitatswachstum in der deutschen Lebensversicherung. In: Markttransparenz und Produktionseffizienz in der deutschen Lebensversicherung. Munich, Germany: Ludwig- Maximilians University.

Kessner, E. \& Polborn, M. (1999). Eine Effizienzanalyse der deutschen Lebensversicherer-die Best Practice Methode. Zeitschrift für die gesamte Versicherungswissenschaft, 88(2), 469-488.

Khaled, M., Adams, M. B. \& Pickford, M. (2001). Estimates of Scale and Scope Economies in the New Zealand Life Insurance Industry. The Manchester School, 69(3), 327-349.

Khan, P. C. \& Mitra, D. (2015). A Study on Technical Efficiency of Life Insurance Companies Operating in India in the Post Liberalised Regime. A Dynamic Panel Approach. The Indian Journal of Commerce, 68(3), 16-27.

Kim, H. \& Grace, M. F. (1995). Potential Ex Post Efficiency Gains of Insurance Company Mergers (Center for Risk Management and Insurance Research Working Paper No. 95-4). Atlanta, GA: Georgia State University.

Kim, Y-D. (2002). WTO Negotiations, Financial Crisis, and Efficiency and Productivity in the Korean Insurance Market [PowerPoint slides]. College of Business and Economics, Soongsil University, Seoul, ROK. 
Kittelsen, S. A. C. (1999). Monte Carlo simulations of DEA efficiency measures and hypothesis tests (Department of Economics Memorandum No. 09/99). Oslo, Norway: University of Oslo.

Klumpes, P. J. M. (2004). Performance Benchmarking in Financial Services: Evidence from the UK Life Insurance Industry. The Journal of Business, 77(2), 257-273.

Klumpes, P. J. M. (2006, May). Consolidation and Efficiency in the Major European Insurance Markets. Paper presented at the Dynamics of Insurance Markets: Structure, Conduct, and Performance in the 21st Century, A Journal of Banking and Finance Conference, Wharton School, University of Pennsylvania, Philadelphia, PA held May 4-5, 2006.

Klumpes, P. J. M. \& Schuermann, S. (2011). Corporate, Product and Distribution Strategies in the European Life Insurance Industry. The Geneva Papers on Risk and Insurance-Issues \& Practice, 36(1), 50-75.

Knezevic, S., Markovic, M. \& Brown, A. (2015). Measuring the Efficiency of Serbian Insurance Companies. Acta Oeconomica, 65(1), 91-105.

Koop, G., Osiewalski, J. \& Steel, M. F. J. (1994). Bayesian Efficiency Analysis with a Flexible Form: The AIM Cost Function. Journal of Business \& Economic Statistics, 12(3), 339-346.

Lai, G. C., Chou, L-Y. \& Chen, L. R. (2015). The Impact of Organizational Structure and Business Strategy on Performance and Risk-taking Behavior in Insurance Industry. Applied Finance and Accounting, 1(2), 107-28.

Lee, Y-C. \& Yang, Y. (2014). Data envelopment analysis with missing data: An application to Life insurance industry in Taiwan. Journal of Economic \& Financial Studies, 2(6), 43-52.

Leverty, J. T. \& Grace, M. F. (2008, July). Issues in measuring the efficiency of property-liability insurers. Paper presented at the Risk Management Laboratory - Uses of Frontier Efficiency Methodologies for Performance Measurement in the Financial Services Sector, Imperial College Business School, London, UK held July 4-5, 2008.

Leverty, J. T., Lin, Y. \& Zhou, H. (2004). Firm Performance in the Chinese Insurance Industry (Center for Risk Management and Insurance Research Working Paper No. 04-10). Atlanta, GA: Georgia State University.

Leverty, J. T., Lin, Y. \& Zhou, H. (2009). WTO and the Chinese Insurance Industry. The Geneva Papers on Risk and Insurance-Issues \& Practice, 34(3), 440-465.

Li, C-H. \& Zhang, W. (2005). Size Vs Efficiency of the Firm: An Empirical Research with DEA Method on Insurance Firms in China. Systems Engineering, 23(9), 37-41.

Li, L. (2011). Efficiency Analysis of Life Insurance Companies in Thailand. Bangkok, Thailand: School of Business, University of the Thai Chamber of Commerce.

Liang, Q. \& Lu, J. (2011). Study on the Efficiency of Life Insurance Industry in China Based on Threestage Data Envelopment Analysis. Economic Management, 33(7), 149-55.

Lin, H-D., Lee, Y-H. \& Shih, M-L. (2011). A Study on Technical Efficiency and Productivity Changes of Taiwan's Life Insurance Industry. Journal of Global Business Management, 7(2), 1-8.

Lin, L. (2003, August). The Impact of Deregulation on the Efficiency of Taiwan Life Insurance Industry. Paper presented at the International Conference of Pacific Rim Management, Seattle, WA held August 1-3, 2003.

Liu, L. \& Kubo, H. (2011). Empirical Study on Efficiency of Japanese Life Insurance Industry: 19982008. Mathematics in Practice and Theory, 41(23), 62-71.

Liu, Y. M. \& Liu, X-H. (2010). Empirical Analysis on Operation Efficiency and Efficiency Continuity of China's Life Insurance Companies. Journal of Qingdao University (Natural Science Edition), 23(3), 69-74.

Lu, W-M., Wang, W-K. \& Kweh, Q. L. (2014). Intellectual capital and performance in the Chinese life insurance industry. Omega, 42(1), 65-74.

Mahlberg, B. (1999). Effizienzmessung österreichischer und deutscher Versicherungen - Ein Vergleich. Wirtschaftspolitische Blätter, 46(4), 400-06.

Mahlberg, B. (2000). Efficiency Progress and Productivity Change in Germany's Insurance Industry. Jahrbücher für Nationalökonomik und Statistik, 220(5), 565-91. 
Mahlberg, B. \& Url, T. (2000). The Transition to the Single Market in the German Insurance Industry (Austrian Institute for Economic Research (WIFO) Working Paper 131). Vienna, Austria: WIFO.

Mahlberg, B. \& Url, T. (2003). Effects of the single market on the Austrian insurance industry. Empirical Economics, 28(4), 813-838.

Mahlberg, B. \& Url, T. (2010). Single Market effects on productivity in the German insurance industry. Journal of Banking \& Finance, 34(7), 1540-1548.

Mansor, S. A. \& Radam, A. (2000). Productivity and Efficiency Performance of the Malaysian Life Insurance Industry. Jurnal Ekonomi Malaysia, 34, 93-105.

Marie, A., Rao, A. \& Kashani, H. (2009). Cost Efficiency and Value Driver Analysis of Insurers in an Emerging Economy. Managerial and Decision Economics, 30(4), 265-280.

Meador, J. W., Ryan, Jr., H. E. \& Schellhorn, C. D. (1997). Product Focus versus Diversification: Estimates of X-Efficiency for the US Life Insurance Industry (Financial Institutions Center, The Wharton School Working Paper No. 97-16). Philadelphia, PA: University of Pennsylvania.

Medved, D. \& Kavcic, S. (2010): An Empirical Study of Efficiency in Croatia and Slovenia in Insurance Markets. Ekonomska istraživanja (Economic Research), 25(1), 105-120.

Miniaoui, H. \& Anissa, C. (2014). Technical Efficiency of Takaful Industry: A Comparative Study of Malaysia and GCC Countries (Working Paper 2014-055). Paris France: IPAG Business School.

Mousavia, M. \& Jafari, S. M. (2015). Measuring the relative efficiency of insurance industry: Evidence from Tehran Stock Exchange. Management Science Letters, 5(11), 999-1004.

Naini, S. G. J. \& Nouralizadeh, H. R. (2012). A Two-Stage DEA to Analyze the Effect of Entrance Deregulation on Iranian Insurers: A Robust Approach. Mathematical Problems in Engineering, 2012, 1-24.

National Association of Insurance Commissioners (NAIC) (2015). Life Insurance Industry-Individual Company Data, Statistical Compilation of Annual Statement Information for Life/Health Insurance Companies in 2014, pp. 132-84. Washington, DC: NAIC. Retrieved from http://www.naic.org/documents/prod_serv_statistical_sta_ls.pdf

Nektarios, M. \& Barros, C. P. (2010). A Malmquist Index for the Greek Insurance Industry. The Geneva Papers on Risk and Insurance-Issues \& Practice, 35(2), 309-324.

Nini, G. P. (2002). An Efficiency Analysis of Foreign and Domestic Insurance Companies in the European Union (Unpublished doctoral dissertation). Philadelphia, PA: University of Pennsylvania.

Noronh, M. R. \& Shinde, S. R. (2012). A Comparative Study of Cost Efficiency of Life Insurance Companies in India. Ganpat University (Kherva, India) Faculty of Management Studies Journal of Management and Research (GFJMR), 4, 1-14.

Office of the Superintendent of Financial Institutions (Bureau du surintendant des institutions financières Canada) (OSFI) (2014). Detailed Historical OSFI Data (Données historiques détaillées $\begin{array}{llllll}d u & \text { BSIF) } & 2014 & \text { Q4 } & \text { (Annual). } & \text { Retrieved }\end{array}$ http://osfi.beyond2020.com/TableViewer/document.aspx?ReportId=2245 and http://osfi.beyond2020.com/TableViewer/document.aspx?ReportId=2246

Ouyang, Q-D. \& Zou, P-F. (2008). An Empirical Analysis on the X- Efficiency and Scale Efficiency of Chinese Life Insurance Industry. Journal of Xiangtan University (Philosophy and Social Sciences), 32(2), 29-34.

Paradi, J. C. (2002). Profit Efficiency - Health Insurance. In N. K. Avkiran, (Ed.), Productivity Analysis in the Service Sector: with Data Envelope Analysis. Camira (suburb of Brisbane), Qld: N. K. Avkiran.

Park, B. U. \& Simar, L. (1992). Efficient Semiparametric Estimation in Stochastic Frontier Models (Department of Economics, Center for Operations Research and Econometrics Discussion Paper 9213). Louvain la Neuve (suburb of Ottignies-Louvain-la-Neuve), Belgium: Catholic University of Louvain.

Peng, J-L., Chen, R-L. \& Liu, W. P. (2014). The Bancassurance Cooperation Strategy and Efficiency of Life Insurance Companies. Academia Economic Papers, 42(2), 235-269.

Pottier, S. W. (2011). Life insurer efficiency and state regulation: evidence of optimal firm behaviour. Journal of Regulatory Economics, 39(2), 169-93. 
Qiu, S. \& Chen, B. (2006, July). Efficiencies of Life Insurers in China: An Application of Data Envelopment Analysis. Paper presented at the 2006 China International Conference in Finance, Xi'an, PRC held July 17-20, 2006.

Rahman, A. (2013). Comparative Study on the Efficiency of Bangladeshi Conventional and Islamic Life Insurance Industry: A Non-Parametric Approach. Asian Business Review, 2(3), 88-99.

Rahman, A., Begum, N. N. \& Anisuzzaman, M. (2014). Efficiency Comparison between Life and NonLife takaful operators in Bangladesh-A Non Parametric Approach. IOSR Journal of Business and Management, 16(12), 38-49.

Rai, A. (1996). Cost Efficiency of International Insurance Firms. Journal of Financial Services Research, 10(3), 213-233.

Rao, A., Kashani, H. \& Marie, A. (2010). Analysis of managerial efficiency in insurance sector in the UAE: an emerging economy. International Journal of Managerial Finance, 6(4), 329-343.

Ray, S. C. \& Desli, E. (1997). Productivity Growth, Technical Progress, and Efficiency Change in Industrialized Countries: Comment. The American Economic Review, 87(5), 1033-1039.

Rees, R., Kessner, E., Klemperer, P. \& Matutes, C. (1999). Regulation and Efficiency in European Insurance Markets. Economic Policy, 14(29), 363-397.

Ren, Y-Y. \& Ma, J. (2013). Analysis of Influencing Factors of Chinese Life Insurance Companies' Scale Efficiency - On the Basis of Panel Threshold Regression Model. Journal of Applied Statistics and Management, 32(4), 740-748.

Ryan, Jr., H. E. \& Schellhorn, C. D. (2000). Life Insurer Cost Efficiency Before and After Implementation of the NAIC Risk-Based Capital Standards. Journal of Insurance Regulation, 18(3), 362-382.

Saad, N. M. \& Idris, N. E. H. (2011). Efficiency of Life Insurance Companies in Malaysia and Brunei: A Comparative Analysis. International Journal of Humanities and Social Science, 1(3), 111-122.

Saad, N. M., Majid, M. S. A., Yusof, R. M., Duasa, J. \& Rahman, A. R. A. (2006). Measuring Efficiency of Insurance and Takaful Companies in Malaysia Using Data Envelopment Analysis (DEA). Review of Islamic Economics, 10(2), 5-26.

Saeidy, P. \& Kazemipour, S. A. (2011). Compare the Performance of Private and Public Insurance Companies in Using Data Envelope Analysis. World Applied Sciences Journal, 13(5), 988-992.

Schmidt, P. \& Sickles, R. C. (1984). Production Frontiers and Panel Data. Journal of Business \& Economic Statistics, 2(4), 367-374.

Segal, D. (2002). An Economic Analysis of Life Insurance Company Expenses. North American Actuarial Journal, 6(4), 81-94.

Seth, P. \& Patel, G. N. (2014). Rashtriya Swasthaya Bima Yojana using Data Envelopment Analysis Approach. Journal of Health Management, 16(2), 199-215.

Sexton, T. R. \& Lewis, H. F. (2003). Two-Stage DEA: An Application to Major League Baseball. Journal of Productivity Analysis, 19(2/3), 227-249.

Shahroudi, K., Taleghani, M. \& Mohammadi, G. (2011). Efficiency Decomposition in Data Envelopment Analysis: An application to Insurance companies in Iran. Interdisciplinary Journal of Contemporary Research in Business, 3(4), 676-684.

Simar, L. \& Wilson, P. W. (1998). Sensitivity Analysis of Efficiency Scores: How to Bootstrap in Nonparametric Frontier Models. Management Science, 44(1), 49-61.

Simar, L. \& Wilson, P. W. (2000). Statistical Inference in Nonparametric Frontier Models: The State of the Art. Journal of Productivity Analysis, 13(1), 49-78.

Simar, L. \& Wilson, P. W. (2008). Statistical Inference in Nonparametric Frontier Models: Recent Developments and Perspectives. In H. O. Fried, C. A. Knox Lovell \& S. S. Schmidt (Eds.), The Measurement of Productive Efficiency and Productivity Growth (Chapter 4). New York, NY: Oxford University Press.

Singh, A. \& Zahran, Z. (2013). A Comparison of the Efficiency of Islamic and Conventional Insurers. Towers Watson Perspectives, 2013. New York, NY: Towers Watson

Sinha, R. P. (2007a). Operating Efficiency of Life Insurance Companies: An Assurance Region Model. Artha Vijnana, 49(3-4), 305-320. 
Sinha, R. P. (2007b). Premium Income of Indian Life Insurance Industry - A Total Factor Productivity Approach. The IUP Journal of Financial Economics, 5(1), 61- 69.

Sinha, R. P. (2010). Revenue Maximizing Efficiency of Life Insurance Companies: Some Indian Evidence. The IUP Journal of Risk \& Insurance, 7(3), 19-37.

Sinha, R. P. (2014). Policy Lapsation Risk and Technical Efficiency: Evidence from Indian Life Insurance Sector. The IUP Journal of Financial Risk Management, 11(1), 25-33.

Sinha, R. P. (2015). A Dynamic DEA Model for Indian Life Insurance Companies. Global Business Review, 16(2), 1-12.

Sinha, R. P. \& Chatterjee, B. (2009, January). Are Indian Life Insurance Companies Cost Efficient? Paper presented at the 11th Annual Conference on Money and Finance, Indira Gandhi Institute of Development Research, Mumbai, India held January 23-24, 2009.

Stevenson, R. E. (1980). Likelihood Functions for Generalized Stochastic Frontier Estimation. Journal of Econometrics, 13(1), 57-66.

Sun, L. \& Li, G-J. (2005). DEA Method in Competition Ability Analysis of Insurance Companies. Journal of Xihua University (Philosophy \& Social Sciences), 6(3), 61-63.

Sun, W. \& Zhong, C. (2011). Cost X-efficiency in China's insurance companies: A stochastic frontier approach. African Journal of Business Management, 5(30), 11916-11924.

Tan, H-B., Wong, M-F. \& Law, S-H. (2009). The Effect of Consumer Factors and Firm Efficiency on Malaysian Life Insurance Expenditure. International Journal Business and Society, 10(1), 59-73.

Thanassoulis, E., Portel, M. C. S. \& Despic, O. (2008). Data envelope analysis: The Mathematical Programming Approach to Efficiency Analysis. In H. O. Fried, C. A. Knox Lovell \& S. S. Schmidt (Eds.), The Measurement of Productive Efficiency and Productivity Growth. New York, NY: Oxford University Press.

Thompson, R. G., Singleton, Jr., F. D., Thrall, R. M., Smith, B. A. \& Wilson, M. (1986). Comparative Site Evaluations for Locating a High-Energy Physics Lab in Texas. Interfaces, 16(6), 35-49.

Tian, X-M. \& Li, X-Y. (2013). Analysis on the Operating Efficiency of Chinese Insurance Industry from Microspective Perspective. Research on Economics and Management, 2013(4), 88-94.

Tone, K. (1998). A Slacks-Based Measure of Efficiency in DEA. The Operations Research Society of Japan, 1, 10-11.

Tone, K. \& Sahoo, B. K. (2005). Evaluating cost efficiency and returns to scale in the Life Insurance Corporation of India using data envelopment analysis. Socio-Economic Planning Sciences, 39(4), 261-285.

Trigo Gamarra, L. (2008). The Effects of Liberalization and Deregulation on the Performance of Financial Institutions: The Case of the German Life Insurance Market (Institut für Volkswirtschaftslehre (Institute of Economics) Working Paper No. 93). Rostock, Germany: University of Rostock.

Trigo Gamarra, L. \& Growitsch, C. (2008, July). Single-versus Multi-Channel Distribution Strategies in the German Life Insurance Market. Paper presented at the Risk Management Laboratory - Uses of Frontier Efficiency Methodologies for Performance Measurement in the Financial Services Sector, Imperial College Business School, London, UK held July 4-5, 2008.

Tulkens, H. (1993). On FDH Efficiency Analysis: Some Methodological Issues and Applications to Retail Banking, Courts and Urban Transit. In P. Chandler, J. Dreze, C. Knox Lovell \& J. Mintz (Eds.), Public Goods, Environmental Externalities and Fiscal Competition (pp. 311-342). New York, NY: Springer, 2006.

Ubl, E. (2010). Ownership and Efficiency in the German Life Insurance Market: A DEA Bootstrap Approach. University of Vienna, Vienna, Austria.

Vanden Eeckaut, P., Tulkens, H. \& Jamar, M. A. (1993). Cost Efficiency in Belgian Municipalities. In H. O. Fried, C. A. Knox Lovell \& S. S. Schmidt (Eds.), The Measurement of Productive Efficiency: Techniques and Applications. New York, NY: Oxford University Press.

Vencappa, D., Fenn, P. \& Diacon, S. R. (2008). Parametric Decomposition of Total Factor Productivity Growth in the European Insurance Industry: Evidence from Life and Non-Life 
Companies (Centre for Risk and Insurance Studies, Nottingham University Business School Working Paper). Nottingham (suburb of Nottingham Urban Area), UK: Nottingham University.

Wang, J. L., Jeng, V. \& Peng, J. L. (2007). The Impact of Corporate Governance Structure on the Efficiency Performance of Insurance Companies in Taiwan. The Geneva Papers on Risk and Insurance-Issues \& Practice, 32(2), 264-282.

Wang, J. L., Peng, J-L. \& Chang, Y-H. (2006). The Impact of Bancassurance on the Efficiency Performance of Life Insurance Companies in Taiwan. National Taiwan University Management Review, 17(1), 59-90.

Wang, Y-W. (2002). Measuring Cost Efficiency of the Life Insurance Industry in Taiwan. (Unpublished Master's Thesis), Chaoyang University of Technology, Taichung, ROChina.

Ward, D. R. (2002). The costs of distribution in the UK life insurance market. Applied Economics, 34(15), 1959-1968.

Weiss, M. A. (1986). Analysis of Productivity at the Firm Level: An Application to Life Insurers. Journal of Risk and Insurance, 53(1), 49-84.

Wu, D., Yang, Z., Vela, S. \& Liang, L. (2007). Simultaneous analysis of production and investment performance of Canadian life and health insurance companies using data envelopment analysis. Computers \& Operations Research, 34(1), 180-198.

Wu, H. \& Zeng, X-F. (2011). Application of Computer Technology in Efficiency Analysis of China Life Insurance Company. Journal of Computers, 6(9), 1832-1841.

Wu, S., Cao, Z., Qin, K., Lang, W. \& Zhang, R. (2012). Empirical Analysis of the Operating Efficiency of China's Insurance Industry. Interdisciplinary Journal of Contemporary Research in Business, 4(8), 12-28.

Wu, Y-M., Li, C-P. \& He, J. (2005). Efficiency Appraisal of China Insurance. Statistics \& Information Tribune, 20(5), 56-70.

Xie, X., Lu, W., Reising, J. \& Stohs, M. H. (2011). Demutualisation, Control and Efficiency in the U.S. Life Insurance Industry. The Geneva Papers on Risk and Insurance-Issues \& Practice, 36(2), $197-$ 225.

Yang, C. C. (2014). Health Care Reform, Efficiency of Health Insurers, and Optimal Health Insurance Markets. North American Actuarial Journal, 18(4), 478-500.

Yang, M-M. (2010). On the Efficiency of China's Insurance Industry after Foreign Insurance Entering. Journal of Yunyang Teachers College, 30(4), 94-97.

Yang, Z. (2006). A two-stage DEA model to evaluate the overall performance of Canadian life and health insurance companies. Mathematical and Computer Modelling, 43(7-8), 910-919.

Yao, S., Han, Z. \& Feng, G. (2007). On technical efficiency of China's insurance industry after WTO accession. China Economic Review, 18(1), 66-86.

Yuan, Y. \& Phillips, R. D. (2008). Financial Integration and Scope Efficiency in U.S. Financial Services Post Gramm-Leach-Bliley (Financial Institutions Center, The Wharton School Working Paper No. 08-32). Philadelphia, PA: University of Pennsylvania.

Yue, P. (1991). A Microeconometric Approach to Estimating Money Demand: The Asymptotically Ideal Model. Federal Reserve Bank of St. Louis Review, November/December 1991, 36-51.

Yuengert, A. M. (1993). The measurement of efficiency in life insurance: Estimates of a mixed normalgamma error model. Journal of Banking \& Finance, 17(2-3), 483-496.

Yusop, Z., Radam, A., Ismail, N. \& Yakob, R. (2011). Risk management efficiency of conventional life insurers and Takaful operators. Insurance Markets and Companies: Analyses and Actuarial Computations, 2(1), 58-68.

Zanghieri, P. (2009). Efficiency of European Insurance Companies: Do Local Factors Matter? (Research Department, Association of Italian Insurers (ANIA), Working Paper). Rome, Italy: ANIA.

Zhao, G-Q. (2009). The efficiency of China's life insurance companies and an analysis on influencing factors - Based on modified two-stage DEA method. Insurance Studies, 2009(10), 38-44. 
Zhao, G-Q. \& Wu H. (2010). The Empirical Analysis of Slack-Based-Measure Efficiency in China's Insurance Industry-Based on Modified Three-stage Data Envelopment Analysis. Journal of Financial Economics, 25(5), 72-84.

Zhi, Y. \& Hu, J-L. (2011). A cross-strait comparative study of efficiency of life insurance companies: An application of the input slack adjustment approach. African Journal of Business Management, 5(14), 5746-5752.

\section{Appendix}

The studies surveyed in this article, along with the methods used therein to determine efficiency, are listed in Table A below:

Table A

Life insurance efficiency studies in survey and method used to determine efficiency

\begin{tabular}{|c|c|c|}
\hline Author(s) & Year & Method(s) \\
\hline Afza, \& Jam-e-Kausar Ali Asghar & 2010 & DEA \\
\hline Afza \& Jam-e-Kausar Ali Asghar & 2012 & N/A \\
\hline Ahmad et al. & 2013 & SFA \\
\hline Al-Amri et al. & 2014 & DEA \\
\hline Al-Amri et al. & 2012 & DEA \\
\hline Alhassan \& Addison & 2013 & DEA \\
\hline Ansah-Adu et al. & 2012 & DEA \\
\hline Aoba & 2006 & SFA \\
\hline Asai et al. & Unknown & DEA \\
\hline Atiquzzafar \& Uzma & 2014 & DEA \\
\hline Badunenko et al. & 2006 & DEA \\
\hline Barros et al. & 2005 & DEA \\
\hline Barros et al. & 2005 & SFA \\
\hline Barros et al.. & 2008 & DEA \\
\hline Barros et al. & 2014 & DEA \\
\hline Barros et al. & 2010 & DEA \\
\hline Barros \& Obijiaku & 2007 & DEA \\
\hline Berger et al. & 2000 & SFA \\
\hline Berger \& Humphrey & 1997 & N/A \\
\hline Bernier \& Sedzro & 2003 & DEA \\
\hline Biener \& Eling & 2012 & DEA \\
\hline Biener et al. & 2014 & DEA \\
\hline Bikker & 2012 & SFA \\
\hline Bikker \& van Leuvensteijn & 2008 & SFA \\
\hline Boonyasai & Unknown & DEA \\
\hline Boonyasai et al. & 2002 & DEA \\
\hline Borges et al. & 2008 & DEA \\
\hline Brockett et al. & 2004 & DEA \\
\hline Cabanda \& Viverita & 2012 & DEA \\
\hline $\mathrm{CaO}$ & 2006 & DEA \\
\hline Carr et al. & 1999 & DEA \\
\hline Chadwick \& Cappelli & 1999 & DEA \\
\hline Chaffai \& Ouertani & 2002 & DEA \& SFA \\
\hline Chakraborty \& Sengupta & 2012 & DEA \\
\hline Chen et al. & 2008 & DEA \\
\hline Chen et al. & 2009 & DEA \\
\hline
\end{tabular}




\begin{tabular}{|c|c|c|}
\hline Chen & 2005 & DEA \\
\hline Chen et al. & 2013 & DEA \\
\hline Chen \& McNamara & 2014 & DEA \\
\hline Chen \& Chang & 2010 & DEA \\
\hline Chiang \& Cheng & 2009 & DEA \\
\hline Chuang \& Tang & 2014 & SFA \\
\hline Cummins & 1999 & DEA \\
\hline Cummins et al. & 2006 & DEA \\
\hline Cummins \& Rubio-Misas & 2001 & DEA \\
\hline Cummins et al. & 2004 & DEA \\
\hline Cummins et al. & 1999 & DEA \\
\hline Cummins et al. & 1999 & DEA \\
\hline Cummins et al. & 1996 & DEA \\
\hline Cummins \& Weiss & 2000 & DEA \\
\hline Cummins et al. & 2010 & DEA \\
\hline Cummins et al. & 2003 & DEA \\
\hline Cummins \& Xie & 2009 & DEA \\
\hline Cummins \& Zi & 1997 & DEA \& SFA \\
\hline Cummins \& $\mathrm{Zi}$ & 1998 & DEA \& SFA \\
\hline Dalkihc \& Ada & 2014 & DEA \\
\hline Davutyan \& Klumpes & 2008 & DEA \\
\hline Deng & 2010 & DEA \\
\hline Diacon et al. & 2002 & DEA \\
\hline Donni \& Fecher & 1997 & DEA \\
\hline Donni \& Hamende & 1993 & FDH \\
\hline Dutta \& Sengupta & 2010 & DEA \\
\hline Dutta \& Sengupta & 2011 & DEA \\
\hline Eling \& Luhnen & 2010 & N/A \\
\hline Eling \& Luhnen & 2010 & DEA \& SFA \\
\hline Ennsfellner et al. & 2004 & Bayesian \\
\hline Erhemjamts \& Leverty & 2010 & DEA \\
\hline Faruk \& Rahaman & 2015 & DEA \\
\hline Fecher et al. & 1993 & DEA \& SFA \\
\hline Fenn et al. & 2008 & SFA \\
\hline Fiordelisi \& Ricci & 2011 & SFA \\
\hline Fuentes et al. & 2001 & SFA \\
\hline Fuentes et al. & 2005 & SFA \\
\hline Fukuyama & 1997 & DEA \\
\hline Gaganis et al. & 2013 & SFA \\
\hline Gan \& Hu & 2007 & DEA \\
\hline Gardner et al. & 1993 & DFA \\
\hline Grace \& Timme & 1992 & SFA \\
\hline Greene \& Segal & 2004 & SFA \\
\hline Han \& Wang & 2009 & DEA \\
\hline Нао & 2003 & SFA \\
\hline Hao & 2005 & SFA \& DFA \\
\hline Hao & 2008 & SFA \\
\hline Hardwick & 1997 & SFA \\
\hline Hardwick & 2003 & DEA \\
\hline Hitt & 1999 & DEA \\
\hline Hong & 2010 & DEA \\
\hline
\end{tabular}


Hu et al.

2009 DEA

Huang et al.

Huang et al.

2010

DEA

Huang

2006 SFA

Huang

2007

SFA

Huang

2008

SFA

Huang

2008

Huang \& Yang

2012

SFA

Hussels \& Ward

2004

DEA

Hussels \& Ward

2006

DEA

Hwang \& Gao

2005

Islam et al.

2013

DFA

Ismail et al.

2011

Ismail et al.

2013

Jarraya \& Bouri

2013

Jeng et al.

2007

Karim \& Jhantasana

2005

Kasman \& Turgutlu

2009

Kaur

2015

Kellner \& Mathewson

1983

Kessner

2001

Kessner

2001

Kessner \& Polborn

1999

Khaled et al.

2001

Khan, P. C. \& Mitra, D.

2015

Kim \& Grace

Kim

2002

Klumpes

2004

Klumpes

2006

Klumpes \& Schuermann

2011

Knezevic et al.

Lai et al.

2015

2015

Lee \&Yang

2014

Leverty et al.

Leverty et al.

2004

2009

Li \& Zhang

2005

$\mathrm{Li}$

2011

DFA

Liang \& Lu

2011

Lin et al.

2011

Lin

2003

Liu \& Kubo

2011

DEA

DEA

Liu \& Liu

Lu et al.

2010

2014

Mahlberg

1999

Mahlberg

2000

Mahlberg \& Url

2000

Mahlberg \& Url

2003

DEA

N/A

DEA

SFA

Mahlberg \& Url

2010

Mansor \& Radam

2000

Marie et al.

2009

SFA

DEA

N/A

DEA

DEA

DEA

SFA

DEA

SFA

DEA

SFA

DEA

N/A

DEA

DEA \& SFA

DEA

DEA

DEA

DEA

DEA

DEA

DEA

DEA

DEA

DEA

DEA

DEA

DEA

DEA

DEA

DEA

DEA

DEA \& SFA 


\begin{tabular}{|c|c|c|}
\hline W. Wise / Accounting 3 (2017) & & \\
\hline Meador et al. & 1997 & SFA \\
\hline Medved \& Kavcic & 2010 & DEA \\
\hline Miniaoui \& Anissa & 2014 & DEA \\
\hline Mousavia \& Jafari & 2015 & DEA \\
\hline Naini \& Nouralizadeh & 2012 & DEA \\
\hline Nektarios \& Barros & 2010 & DEA \\
\hline Nini & 2002 & SFA \\
\hline Noronh \& Shinde & 2012 & DEA \\
\hline Ouyang \& Zou & 2008 & SFA \\
\hline Paradi & 2002 & DEA \\
\hline Peng et al. & 2014 & DEA \\
\hline Pottier & 2011 & DEA \\
\hline Qiu \& Chen & 2006 & DEA \\
\hline Rahman & 2013 & DEA \\
\hline Rahman et al. & 2014 & DEA \\
\hline Rai & 1996 & SFA \\
\hline Rao et al. & 2010 & DEA \\
\hline Rees et al. & 1999 & DEA \\
\hline Ren \& Ma & 2013 & DEA \\
\hline Ryan, Jr \& Schellhorn & 2000 & DFA \\
\hline Saad \& Idris & 2011 & DEA \\
\hline Saad et al. & 2006 & DEA \\
\hline Saeidy \& Kazemipour & 2011 & DEA \\
\hline Segal & 2002 & SFA \\
\hline Seth \& Patel & 2014 & DEA \\
\hline Shahroudi et al. & 2011 & DEA \\
\hline Singh \& Zahran & 2013 & DEA, SFA, FDH \\
\hline Sinha & 2007 & DEA \\
\hline Sinha & 2007 & DEA \\
\hline Sinha & 2010 & DEA \\
\hline Sinha & 2014 & DEA \\
\hline Sinha & 2015 & DEA \\
\hline Sinha \& Chatterjee & 2009 & DEA \\
\hline Sun \& Li & 2005 & DEA \\
\hline Sun \& Zhong & 2011 & SFA \\
\hline Tan et al. & 2009 & DEA \\
\hline Tian \& Li & 2013 & DEA \\
\hline Tone \& Sahoo & 2005 & DEA \\
\hline Trigo Gamarra & 2008 & SFA \\
\hline Trigo Gamarra \& Growitsch & 2008 & DEA \\
\hline Ubl & 2010 & DEA \\
\hline Vencappa et al. & 2008 & SFA \\
\hline Wang et al. & 2007 & DEA \\
\hline Wang et al. & 2006 & DEA \\
\hline Wang & 2002 & SFA \\
\hline Ward & 2002 & DFA \\
\hline Wei & 2006 & SFA \\
\hline Weiss & 1986 & SFA \\
\hline Wu et al. & 2007 & DEA \\
\hline Wu \& Zeng & 2011 & DEA \\
\hline Wu et al. & 2012 & SFA \\
\hline
\end{tabular}




\begin{tabular}{lll} 
Wu et al. & 2005 & DEA \\
Xie et al. & 2011 & DEA \\
\hline Yang & 2014 & DEA \\
Yang & 2010 & DEA \\
\hline Yang & 2006 & DEA \\
\hline Yao et al. & 2007 & DEA \\
\hline Yuan \& Phillips & 2008 & SFA \\
Yuengert & 1993 & SFA \\
\hline Yusop et al. & 2011 & DEA \\
\hline Zanghieri & 2008 & SFA \\
\hline Zhao & 2009 & DEA \\
\hline Zhao \& Wu & 2010 & DEA \\
\hline Zhi \& Hu & 2011 & DEA \\
\hline
\end{tabular}

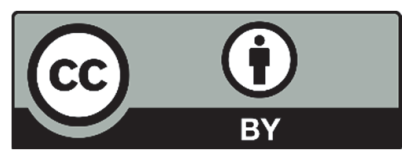

(C) 2016 by the authors; licensee Growing Science, Canada. This is an open access article distributed under the terms and conditions of the Creative Commons Attribution (CC-BY) license (http://creativecommons.org/licenses/by/4.0/). 